\title{
Complexities underlying the breeding and deployment of Dutch elm disease resistant elms
}

\author{
Juan A. Martín ${ }^{1,7}$ (D) Jorge Domínguez ${ }^{1,2}$ - Alejandro Solla ${ }^{3}$. Clive M. Brasier ${ }^{4}$. \\ Joan F. Webber ${ }^{4}$. Alberto Santini ${ }^{5}$. Clara Martínez-Arias ${ }^{1} \cdot$ Louis Bernier $^{6} \cdot$ Luis Gil $^{1}$
}

Received: 7 January 2021 / Accepted: 3 July 2021

(c) The Author(s) 2021

\begin{abstract}
Dutch elm disease (DED) is a vascular wilt disease caused by the pathogens Ophiostoma ulmi and Ophiostoma novo-ulmi with multiple ecological phases including pathogenic (xylem), saprotrophic (bark) and vector (beetle flight and beetle feeding wound) phases. Due to the two DED pandemics during the twentieth century the use of elms in landscape and forest restoration has declined significantly. However new initiatives for elm breeding and restoration are now underway in Europe and North America. Here we discuss complexities in the DED 'system' that can lead to unintended consequences during elm breeding and some of the wider options for obtaining durability or 'field resistance' in released material, including (1) the phenotypic plasticity of disease levels in resistant cultivars infected by $O$. novo-ulmi; (2) shortcomings in test methods when selecting for resistance; (3) the implications of rapid evolutionary changes in current $O$. novo-ulmi populations for the choice of pathogen inoculum when screening; (4) the possibility of using active resistance to the pathogen in the beetle feeding wound, and low attractiveness of elm cultivars to feeding beetles, in addition to resistance in the xylem; (5) the risk that genes from susceptible and exotic elms be introgressed into resistant cultivars; (6) risks posed by unintentional changes in the host microbiome; and (7) the biosecurity risks posed by resistant elm deployment. In addition, attention needs to be paid to the disease pressures within which resistant elms will be released. In the future, biotechnology may further enhance our understanding of the various resistance processes in elms and our potential to deploy trees with highly durable resistance in elm restoration. Hopefully the different elm resistance processes will prove to be largely under durable, additive, multigenic control. Elm breeding programmes cannot afford to get into the host-pathogen arms races that characterise some agricultural host-pathogen systems.
\end{abstract}

Keywords Dutch elm disease · Breeding · Resistance $\cdot$ Ulmus $\cdot$ Ophiostoma ulmi . Ophiostoma novo-ulmi $\cdot$ Phenotypic plasticity

Juan A. Martín

juan.martin.garcia@upm.es

Extended author information available on the last page of the article 


\section{Introduction}

Species within the genus Ulmus found in Europe and North America were formerly considered keystone species, but nowadays this status is severely degraded due to the global impacts of two fungal pathogens in the genus Ophiostoma: the causal agents of Dutch elm disease (DED). The first DED pandemic emerged in Europe in the first decades of the twentieth century and was caused by the introduction of Ophiostoma ulmi, which is moderately aggressive to European elms but highly aggressive to American elm (Ulmus americana) (Gibbs et al. 1975). This pandemic declined unexpectedly from ca 1935s in Europe, but not in North America (Peace 1960; Mitchell and Brasier 1994; Brasier and Webber 2019). Subsequently, a second, highly destructive pandemic caused by the introduction of $O$. novo-ulmi emerged in both continents. O. novo-ulmi proved to be highly aggressive towards both European and North American elms, and has now replaced $O$. ulmi in most locations (Brasier 2000a; Solla et al. 2008). The ability of some elm species to resprout vegetatively from the roots or reproduce abundantly by seeds has resulted in a post-epidemic phase in which recurrent cycles of high disease continue to occur in the recruitment trees once they reach 3-10 m in height (Brasier 1986a; Martín et al. 2019a; Brasier and Webber 2019) (Fig. 1a, b).

Since the pioneering work of Dutch workers in the 1930s (Heybroek 1957) many initiatives of elm reintroduction and restoration have been launched (Knight et al. 2017; Martín et al. 2019a) (Fig. 1c, d). The diversity of products and services derived from elms e.g., ecosystem protection, ornamental and landscape value, shade, timber and wood materials, biomass, nanomaterials (Heybroek 1993; Richens 1983; Martín-Sampedro et al. 2019; Mehmood 2019; Jiménez-López et al. 2020) are good reasons to promote the recovery of the elms. Current restoration initiatives use knowledge, techniques and plant materials developed by several different breeding programs and research groups (Smalley and Guries 1993; Mittempergher and Santini 2004; Pecori et al. 2017). Restoration of founder populations of elms should rely on two basic principles: availability of genetically diverse and arboriculturally suitable material resistant to DED (including native elm individuals) and deployment of appropriate planting strategies. Currently, both these requirements are far from optimal and elm restoration is still in its infancy.

In relation to plant material, availability of DED-resistant cultivars known to be suitably adapted for planting in natural habitats remains scarce, although in the next decade its availability is expected to increase (Pinchot et al. 2017; Martín et al. 2015, 2019a). A considerable number of hybrids obtained by interspecific crosses between susceptible native European elms and resistant Asian elms are available in the market (Santini et al. 2002, 2007, 2012; Buiteveld et al. 2015), but these are mainly used in urban forestry although their potential for timber or biomass production has been highlighted (Santini et al. 2010). However, because these genotypes are not native, their introduction in natural habitats can be controversial and often conflicts with social, ecological and political concerns. A more pragmatic and less ambitious alternative to the wide scale planting of DED-resistant cultivars is the deployment of diverse elm genotypes with partial resistance, in the knowledge that though many of them will suffer from the disease some may be in the right environment to survive and reproduce. This approach has been adopted by UK Conservation Foundation's 'Great British Elm Experiment', and by several partners involved in elm restoration in France (Collin et al. 2020).

Planting strategies should also be derived from a deep knowledge of the ecology of the species and from experience of appropriate planting and aftercare methods. Because 

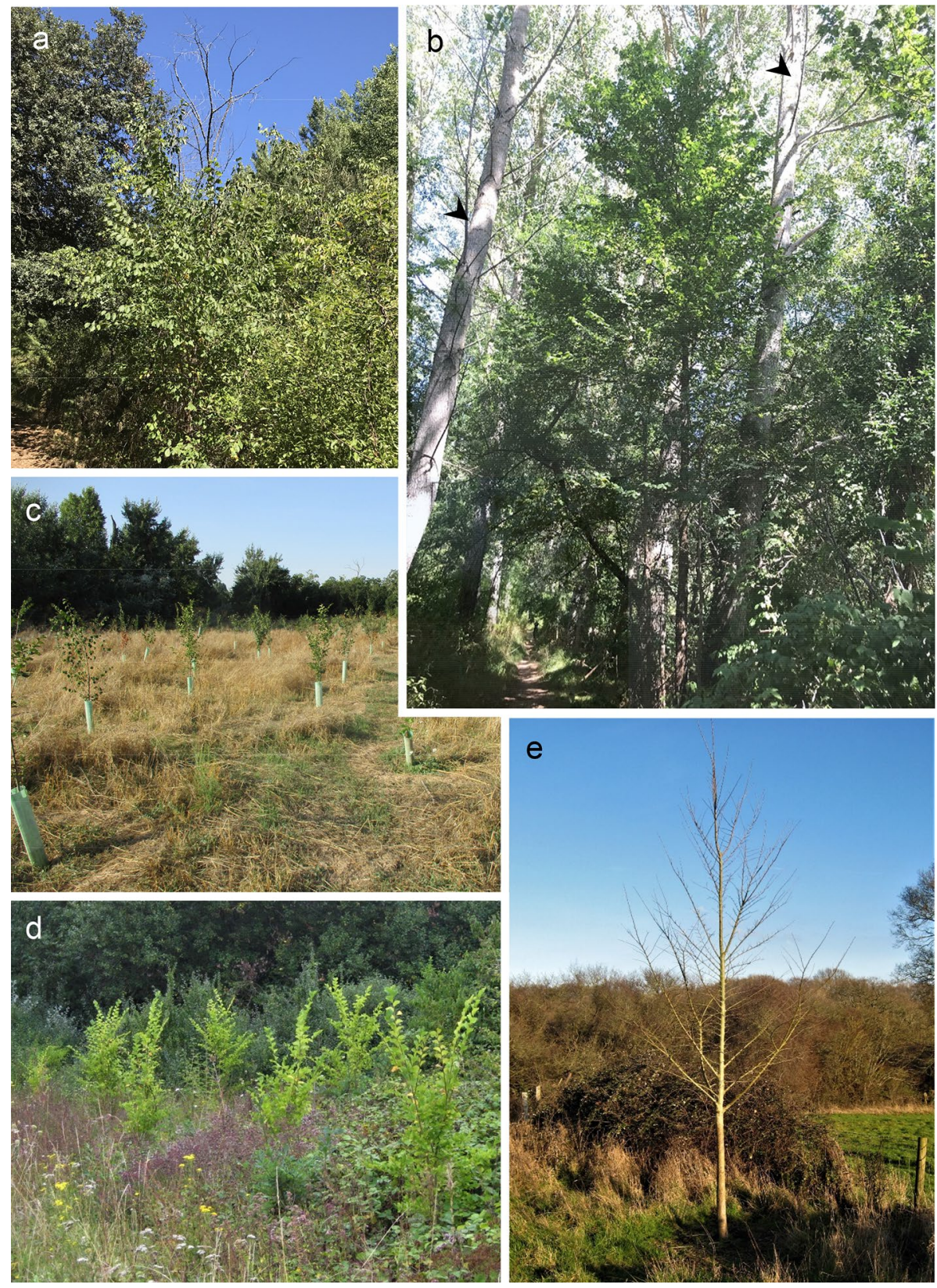

Fig. 1 Natural and reintroduced Ulmus minor trees in Spain and the UK. a Vigorous elm sprouts in an open area of a riparian forest (Ebro River, Burgos, Spain) succumb to DED once they surpass approximately $5 \mathrm{~m}$ in height (see the dieback of the tallest stem). b Slender elm tree of circa $10 \mathrm{~m}$ in height growing in the same riparian forest, but in a closed canopy area dominated by Populus alba trees (arrowheads). In such situation, elms frequently show DED symptoms and rarely become dominant. c Young plantation of Spanish U. minor cultivars resistant to DED in Aranjuez, Madrid. d Plantation of the Spanish cultivar Ademuz, resistant to DED, in Portchester, UK. e Ademuz individual growing vigorously in Hampshire, UK. (Photos d and e kindly provided by Andrew Brookes, Butterfly Conservation) 
the use of elms in forest restoration was almost non-existent during the last century, current knowledge is limited. In spite of such limitations, pilot reintroduction plantings which deploy resistant 'native' U. minor cultivars in Europe (Martín et al. 2019a) and resistant U. americana cultivars in the USA (Knight et al. 2017), should enhance knowledge of elm biology and best planting practices. Common garden experiments (e.g. Martín et al. 2008a; Vivas et al. 2012; Martín et al. 2012; Griffin et al. 2017) and the establishment of experimental field plots used for research (e.g. Solla et al. 2015; Martín et al. 2021) could also enhance the experience needed for adequate elm restoration. Failures in attempts at elm restoration often arise from negative interactions between the planted cultivars and the environment e.g. ambient temperatures and soil moisture conditions. There is a need therefore, for breeders to identify negative interactions with the material before its release, and to properly inform foresters and arboriculturalists about any limitations on the performance of selected cultivars under certain conditions. For instance, the U. minor cultivar Christine Buisman, originally from Spain, was the first resistant cultivar released by the Dutch breeding program in 1937. However, it showed a poor adaptation to the Netherlands climate, being highly susceptible to coral-spot Nectria canker (Heybroek 1957).

When resistance to DED is described here, it will refer to host resistance expressed in the xylem vessels after infection - the vascular wilt phase of the pathogen (Fig. 2; Webber and Brasier 1984). However, the pathogen has multiple ecological phases such that resistance to infection also occurs in the beetle feeding wounds prior to xylem infection, and this resistance may be a different process from that occurring in the xylem vessels (Webber and Brasier 1994). In addition, resistance will also occur in elm bark when the pathogen invades in association with scolytid elm bark beetles (Webber et al. 1988). DED resistance to the pathogen is variable among elm species and genotypes within species, and relies on constitutive and inducible defence mechanisms, with expression controlled by several genes (Townsend 2000; Aoun et al. 2010; Sherif et al. 2016; Beier and Blanchette 2018). Since the probable multigenic control processes involved in the resistance of elms to DED are poorly characterised and understood the potential use of genetic markers to accelerate selection for resistance, also remains limited. In this regard genome sequencing should be used in future to enhance breeding protocols through genome-enabled selection (Resende et al. 2012). This approach would use genomic information to predict the traits of interest and, consequently, reduce the time and cost of breeding. Genomic prediction models of DED resistance will, however, require complex studies involving large trials and accurate phenotyping of 'resistance'. Attempts to produce DED resistant elms via genetic engineering, including the development of associated protocols of elm tissue culturing, induction of somaclonal variation and elm genetic transformation, were pioneered in the 1990s (e.g. Fenning et al. 1996; Gartland et al. 2000a,b, 2001) and may also play a significant role in the future.

The phenotype of a particular elm genotype is often strongly dependent on the environment where it develops and even on a particular season. The assessment of genotype $\times$ environment $(\mathrm{G} \times \mathrm{E})$ interaction, i.e. the relative impact of different environmental changes on the phenotype (Isik and Kleinschmit 2003), should be determined in order to define the range of environmental conditions where a genotype would grow, reproduce and express resistance (Santini et al. 1997). The phenomenon of a genotype producing different phenotypes in response to different environmental conditions is known as phenotypic plasticity (Ghalambor et al. 2007). In DED, phenotypic plasticity of seasonal differences that occur in elms responding to infection has been described as a combination of host $\times$ environmental interactions prior to infection (host preconditioning), and fungal genotype $\times$ host genotype $\times$ environment interactions during and after infection (Brasier 1987). Although outstanding progress has been made in 


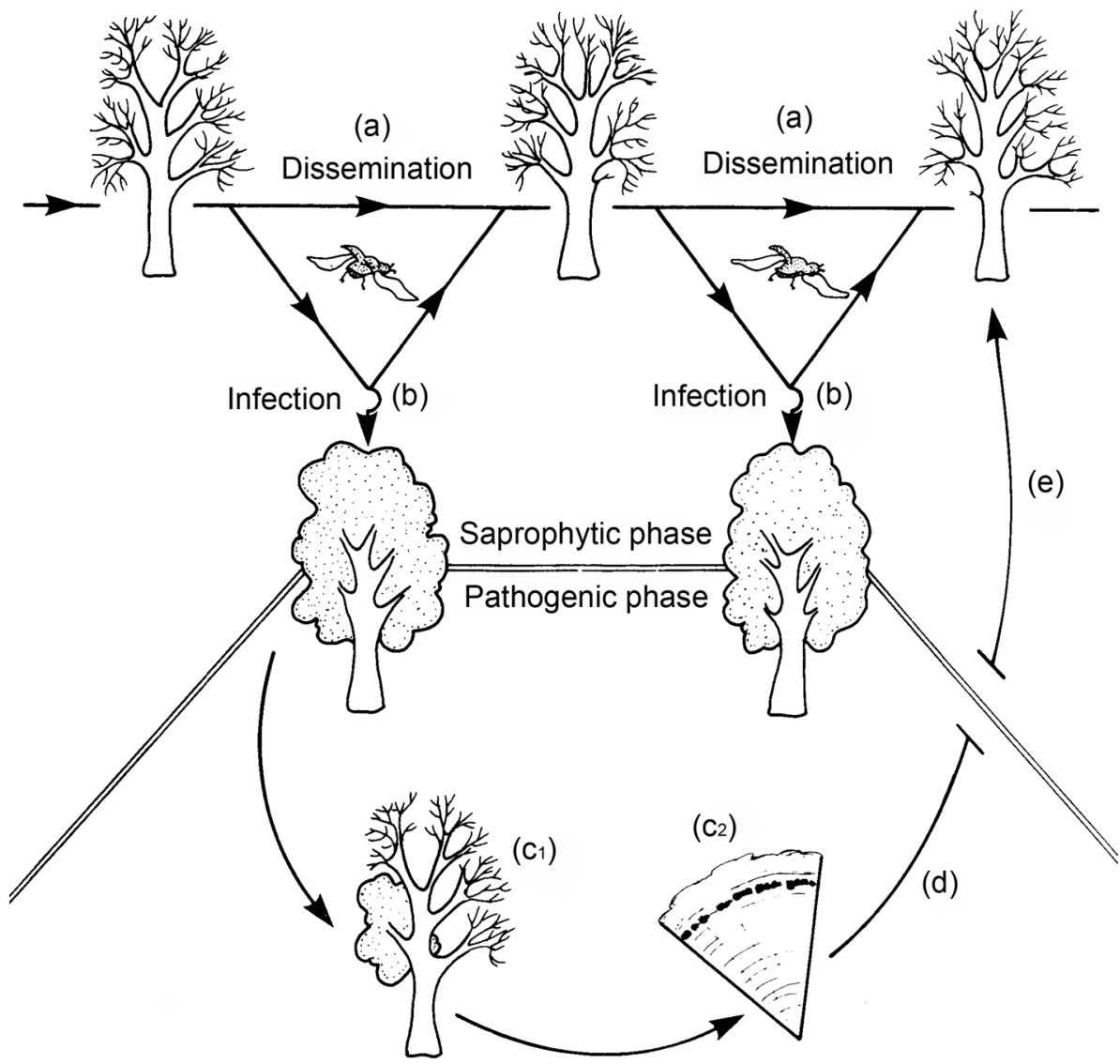

Fig. 2 The two cycles of the pathogen in Dutch elm disease. $\mathbf{a} \rightarrow \mathbf{a}$ The continuous bark to bark cycle of the saprotrophic phase. $\mathbf{b} \rightarrow \mathbf{d}$ The pathogenic phase side loop, associated with beetle feeding and xylem infection. Adapted from Webber and Brasier (1984). e Studies with genetically marked isolates demonstrated that some genotypes from the pathogenic phase eventually feed back into the saprotrophic phase gene pool (Webber et al. 1988)

understanding plasticity of plant traits in response to abiotic factors, response to biotic factors has received considerably less attention (Solla et al. 2016; Valladares et al. 2007). Here we aim to explore the extent to which DED resistance is a plastic trait, the causes of this plasticity, and factors that could limit the negative impact of such plasticity in restoration programs. We will also consider how to avoid unintended consequences arising from the complexity of the 'DED system' when deploying DED resistant elms. For this purpose, early research on DED has been reviewed and contrasted with more recent research, with a particular focus on the experiences of the Spanish elm breeding program and UK studies on the pathogens and vectors. 


\section{Phenotypic plasticity of foliage wilting of selected elms in response to DED}

In recent years, interest in planting DED resistant cultivars has been growing in Europe and North America. Given the scarcity of native resistant materials, these cultivars need to perform well under a variety of environmental conditions (Fig. 1c-e). Previous research on DED provides consistent evidence that elm resistance is highly plastic, and influenced by several climatic and edaphic factors (Kais et al. 1962; Sutherland et al. 1997; Solla and Gil 2002a). For example, during more than 11 years of elm inoculations at the same site using the single elm genotype $U$. procera SR4 (=U. minor), and the same set of $O$. novo-ulmi genotypes, the ranking of the pathogen genotypes remained the same but disease levels fluctuated from moderately resistant to highly susceptible, the main environmental influences being temperature and light intensity (Fig. 3; Sutherland et al. 1997). The genetic variation underlying such plasticity (i.e. in $\mathrm{G} \times \mathrm{E}$ interactions), however, has been less explored although it is likely to reflect a multigene resistance process. A major initiative to study DED resistance plasticity in the RESGEN 78 EU project (1997-2001), tested the performance of seven elm cultivars in common garden experiments across six European countries (Solla et al. 2005a). The cultivars showed different disease ratings depending on the location and the inoculation year, again indicating that DED resistance is a plastic trait. Although the susceptibility ranking of most cultivars again remained consistent regardless of the location and year, some significant $G \times E$ interactions were observed in the form of the inconsistent susceptibility of two of the elm clones in Germany and Italy. This result suggests that $\mathrm{G} \times \mathrm{E}$ interactions in elm resistance are not frequent, but that some cultivars can be remarkably sensitive to the environment.

To explore phenotypic plasticity of DED resistance in Spain, common garden plots in contrasting environments were recently established. Although the research is still in progress, preliminary data confirms high plasticity of DED resistance and a significant genetic variation in such plasticity. For example, when comparing two experimental locations with contrasting climate, namely Madrid (inland Mediterranean climate; $700 \mathrm{~m}$ above the sea level (m.a.s.l.)) and Valencia (coastal Mediterranean climate; 40 m.a.s.l.), G $\times \mathrm{E}$ interactions in resistance could be observed (Fig. 4). Thus, U. minor cultivar ABAM2.4 performed better in Valencia, in terms of resistance, in comparison to MAPD2, MDV4/5 and QTL97 which in contrast performed better in Madrid (Fig. 4).

Fig. 3 Levels of defoliation of $U$. procera (\%) over eleven climatically variable seasons (1983-1995) caused by $O$. novo-ulmi SSNU isolates of high (filled triangle), medium (filled square) and exceptionally low (filled circle) aggressiveness (same isolates as in Fig. 7). Note the consistent order if the isolates across the tests. Bars, 95\% confidence limits. Adapted from Sutherland et al. (1997)

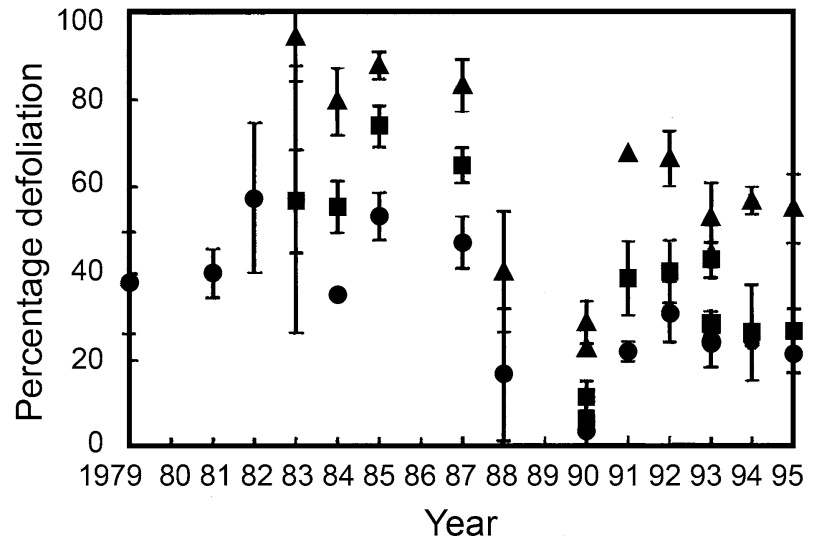


Fig. 4 Interactions in leaf wilting symptoms at 60 days after Ophiostoma novo-ulmi inoculation between six Ulmus minor cultivars and two experimental locations (Madrid vs Valencia, Spain)

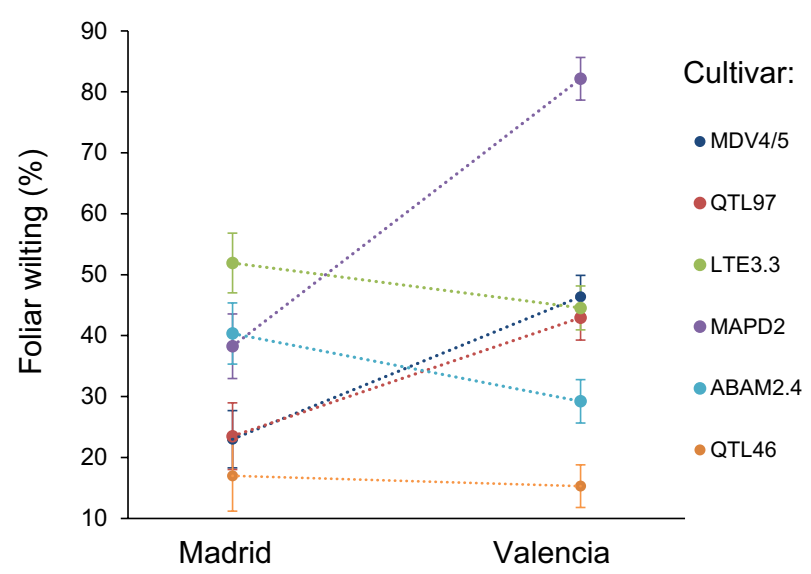

Besides plasticity in DED resistance, other factors not always considered in elm breeding programs could also result in elm restoration failure. These include intolerance of selected cultivars to frost, flooding, wind and drought, and the relative attractiveness/susceptibility of selected cultivars to pests and pathogens such as scolytids, Xanthogaleruca luteola, Cossus cossus, Stegophora ulmea, Nectria canker and elm yellows (Smalley and Guries 1993; Pecori et al. 2017). Moreover, the presence of wild and domestic fauna in the plantation area can also reduce the survival of young trees.

\section{Unintended consequences derived from breeding: factors influencing symptom expression of selected elm cultivars}

Resistant tree breeding is generally a long-term approach requiring sustained investment and a broad knowledge of the factors influencing symptom expression of trees. Loss of public confidence in the deployment of selected material can arise if resistance breaks down or resistant material is susceptible to other biotic or abiotic threats (Woodcock et al. 2019). The main objective of elm breeding is to deploy elms with durable, and therefore what is likely to be multigenic, or even multi-faceted, DED resistance. To this end, it is important to understand the resistance traits operating at different phases of the disease (Fig. 2). During the pathogenic phase in the xylem elms can display a variety of defence mechanisms, whose efficacy in pathogen suppression will lead to a ranking of resistance levels. Defence mechanisms can also be expressed during the colonisation of the inner bark (phloem) by the pathogen and beetle vectors, and during reinfection of elms in the beetle feeding grooves, and these too can translate into different levels of resistance. Furthermore, different elm species and genotypes can express different levels of attraction to the insect vectors. An ideal, though admittedly very ambitious, objective of elm breeding could be to integrate resistance mechanisms acting in different phases of the disease within the same elm genotype or population of genotypes. In the following sub-sections our understanding of the factors that influence resistance at different phases of the disease is reviewed. 


\section{Xylem anatomy and phenology of wood formation}

Secondary xylem of elms has a ring-porous structure. In spring, when water availability is not limiting, elms initially form wide earlywood vessels to optimize hydraulic efficiency, while in late spring and summer, when periods of water stress arise, they form narrow latewood vessels to increase hydraulic safety (Ellmore and Ewers 1985). The DED pathogens take advantage of xylem anatomy to spread efficiently through the wide earlywood conduits in the form of yeast-like blastospores, causing embolisms and inducing a wilt syndrome (Newbanks 1983). The pivotal role of the hydraulic conductive system in DED pathogenesis stimulated the search for anatomical characters involved in susceptibility. Several studies provided evidence that vessel diameter has a role in susceptibility to DED, as elms with narrow earlywood vessels tend to suffer less severe disease symptoms (Elgersma 1970; McNabb et al. 1970; Sinclair 1975; Martín et al. 2013a; Beier and Blanchette 2020). This conclusion is based on several assumptions. First, fungal propagules and toxins are likely to be more efficiently transported in wide conduits, which in turn are more prone to embolism than narrow vessels (Sperry and Tyree 1988; Pouzoulet et al. 2020). Second, the pathogen can be vertically compartmentalized (i.e. walled off) inside vessels if the lumen is blocked with tyloses and gums, but complete blocking of lumen is more difficult in wide vessels (Pouzoulet et al. 2020). Despite this theoretical framework, recent research has revealed that while susceptible $U$. minor trees tend to develop wide earlywood vessels, resistant trees do not always have narrow vessels (Martín et al. 2021). Instead, vessel occlusion by tyloses correlated with resistance only in a group of elms which had narrow earlywood vessels, supporting the hypothesis of easy pathogen compartmentalization in narrow $v s$. wide conduits.

Vessel size has been shown to be a plastic trait in different woody species, mainly influenced by variation in soil moisture content (Lovisolo and Schubert 1998; Solla and Gil 2002b; Martín et al. 2013a; Venegas-González et al. 2015; Noyer et al. 2017). In general, these studies indicate that plants under water stress tend to reduce vessel diameter. Such plasticity allows species to adapt to changing environmental conditions by supporting either hydraulic safety or hydraulic conductance, but in elms it can also potentially affect the DED susceptibility of certain cultivars by reducing susceptibility if environmental conditions induce the formation of narrow vessels. This is particularly relevant in screening tests for DED resistance because appropriate watering in spring and avoidance of stress factors (transplanting, pruning, wounding) is required prior to inoculation in order to facilitate pathogen dispersal within the tree (Tchernoff 1965).

The main period of DED susceptibility starts in spring, after earlywood vessels became fully functional, and lasts for 20-30 days, until a certain proportion of latewood is formed (Banfield 1941; Smalley 1963; Santini et al. 2005a), although this period varies markedly between elm genotypes (Smalley and Kais 1966). The natural synchrony between the peak elm susceptibility and spring flight of adult elm bark beetles which vector the disease (Fransen 1939) therefore contributes to the susceptibility of elms to DED (Solla et al. 2005b). Elm bark beetles in the genera Scolytus and Hylurgopinus transmit pathogen spores during maturation feeding in twigs and branches (Webber 2004; Anderbrant et al. 2017). If asynchrony occurs between DED vector transmission and earlywood vessel formation, disease symptoms are likely to be reduced, or absent (Fig. 5). For this reason, major northern and western range expansions of DED in Britain after the arrival of $O$. novo-ulmi coincided with hotter summers because of the influence on the flight period of the larger elm beetle, S. scolytus (Fairhurst and King 1983). 


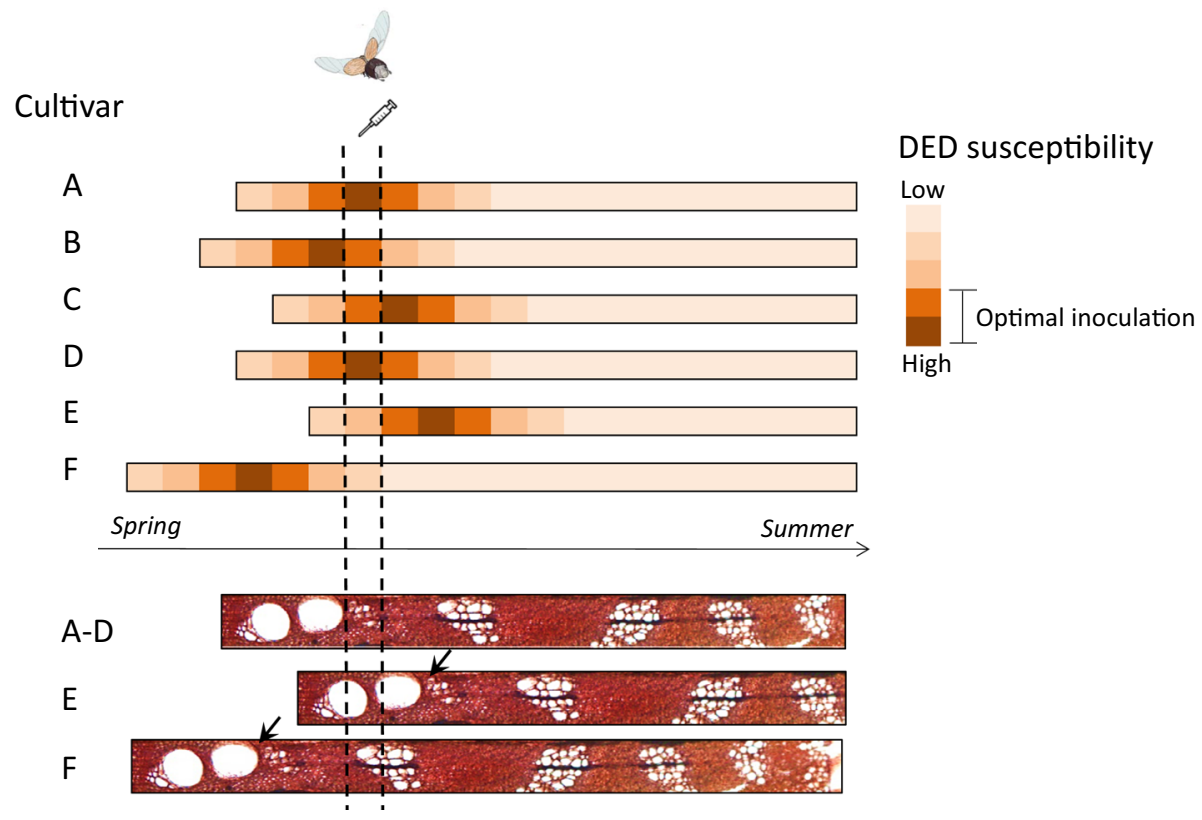

Fig. 5 Diagrammatic representation of the susceptibility window of six elm cultivars to DED, with focus on insect vector flight period, inoculation date and phenology of wood formation. Optimal temporal window for artificial inoculation of cultivars A-D is represented within the two vertical dotted lines. This window often overlaps with the main flight period of adult elm bark beetles which transmit the DED pathogen during maturation feeding. Cultivars A-D are highly susceptible to DED as they have just formed wide earlywood vessels but have not developed latewood (see bottom panels representing xylem development). Cultivar E shows a late phenology; its earlywood vessels are still non-functional and, if inoculated, pathogen spread will be limited. Cultivar F shows an early phenology; by the time of the optimal inoculation window a proportion of latewood has already formed increasing hydraulic safety and decreasing the cultivars susceptibility to the pathogen. To properly characterize the resistance of cultivars $\mathrm{E}$ and $\mathrm{F}$, a different inoculation date should be selected (black arrows)

Other research has found a significant correlation between DED resistance and precocity of flushing in Italian and French $U$. minor clones (Santini et al. 2005a). The authors argued that by time of pathogen inoculation, early flushing genotypes had already completed formation of earlywood vessels and were starting to lay down latewood, having passed the peak susceptibility window. Furthermore, they concluded that earlywood vessel formation is under strong genetic control (Ghelardini et al. 2006, 2010) and therefore could be a selectable trait in breeding programs. Highly significant differences in the timing of growth initiation were also observed among cultivars of $U$. americana but were not consistently associated with disease symptomatology (Townsend et al. 2005).

The timing of wood formation and its influence on DED resistance should therefore be taken into consideration during artificial screening for resistance (Beier et al. 2017a). The inoculation date has to be selected according to the tree phenology, which varies with latitude, climate type (e.g. maritime versus continental), and seasonal conditions (Ghelardini et al. 2006). In European elms, peak susceptibility is reached around 40-50 days after bud break (Tchernoff 1965; Solla and Gil 2003), and therefore monitoring of leaf phenology is strongly advisable, due to variability in phenology among cultivars. Otherwise, there is a risk of selecting 'false' resistant cultivars if susceptible trees are inoculated outside their 
susceptibility window (Fig. 5). To minimize this risk, it is advisable to characterise the phenology timelines of different cultivars before inoculation. If variation between cultivars is pronounced, inoculation should be carried out on different dates. Based on observations made in experimental plots established in Madrid (Spain), small differences in leaf phenology between $U$. minor cultivars were seen (around 5-10 days of variation in bud break among genotypes), but the differences were higher in Valencia (Spain) (around 5-20 days of variation) (unpublished results). While in Madrid it was possible to inoculate different cultivars in a single day, in Valencia cultivars had to be classified into two groups (earlyand late-flushing trees) and inoculated on two different dates. Replication of inoculations across several years and locations is recommended to reduce the risks of false selection of resistant cultivars due to variability in phenology.

\section{The environment and the growth of trees}

It is widely accepted that variation in climatic conditions can significantly alter the level of symptoms caused by DED (Kais et al. 1962; Smalley 1963; Tchernoff 1965; Sutherland et al. 1997). Climatic effects on host physiology, phenology and anatomy, among others, can influence the host response against infection and the ability of the pathogen to spread within the tree. Water shortage before infection has been shown to induce resistance to DED (Sutherland et al. 1997), while water stress after inoculation can enhance susceptibility (Solla and Gil 2002a). Temperature directly affects pathogen growth (Brasier et al. 1981) and the interactions between the host and the pathogen (Sutherland et al. 1997). These influences further highlight the importance of conducting resistance trials over several seasons and at different locations, as well as documenting as much as possible the experimental conditions under which the tests were carried out. Consideration should be also given to the climatic conditions during the process of inoculation. Conditions favouring a high transpiration rate such as hot and sunny weather, and the presence of available soil water will facilitate inoculum absorption and the development of external symptoms (Tchernoff 1965; Solla et al. 2001). For the same reason, inoculation should be preferably performed during the middle period of the day. Besides climate, other abiotic factors can also influence the level of resistance to DED. The presence of phenolic contaminants in soil and their absorption by roots has been shown to induce accumulation of suberin-like compounds in xylem tissues, leading to enhanced resistance to DED (Martín et al. 2008b, $2010 \mathrm{~b}$ ). This process was associated with the survival of $U$. procera trees in a stand in central Spain, where phenolic-based disinfectant products were frequently used for the cattle (Martín et al. 2010a).

Any environmental factor which limits tree growth can potentially increase resistance to DED. Evidence from earlier studies (Heybroek 1957; Kais et al. 1962) and recent research on DED (Martín et al. 2021) indicates that vigorously growing elms tend to develop more severe foliar symptoms. In contrast, soils with a low water retention capacity, long-term flooded soils, infertile soils, or a prolonged dry season can reduce wilting symptoms (Sutherland et al. 1997). Screening tests for resistance need to ensure good physiological plant development before inoculation. Trees that were potted, wounded or placed under physiological stress in the previous year (e.g. by transplanting, pruning or girdling) should be avoided. In experimental plots it is also essential to include at least one susceptible cultivar as a control to check whether any stress factor is reducing plant growth and inducing resistance. Within the Spanish elm breeding program, inoculations performed in experimental plots with constrained tree growth 
resulted in low mean values for DED symptom expression. In addition, if soil properties or any other environmental factors are not uniform across the whole of an experimental plot, it should be divided into blocks to properly distinguish the environmental effects within the plot from host DED susceptibility (see Fig. 6). Despite this general trend, it is important to emphasise that the correlation between growth rate and DED susceptibility is far from absolute at the individual genotype level (Heybroek 1957), and thus resistant cultivars are not necessary always slow growers.

Under current climate change scenarios, where events such as prolonged droughts and flooding are increasingly frequent (IPCC 2014), it is important to characterize resistant cultivars and their potential to tolerate such events, and understand the influence of these events. Scientific data on disturbance tolerance in elms is scarce, and is mainly in regard to intraspecific variation. Optimal zones for planting different resistant cultivars, such as the distance from watercourses or oscillations in water table levels, need to be defined. To this end, pilot forest plantations can offer an ideal experimental framework to monitor the performance of elm cultivars. Such approaches can be further augmented by experiments to broaden our knowledge on elm ecophysiology and responses under different environmental constraints. For instance, Martínez-Arias et al. (2020) recently evaluated under controlled conditions the response of five resistant $U$. minor cultivars to waterlogging, to drought and to a combination of both stresses. They found that the five cultivars were similarly tolerant to drought, but the response to waterlogging and drought after a period of waterlogging significantly varied among genotypes.

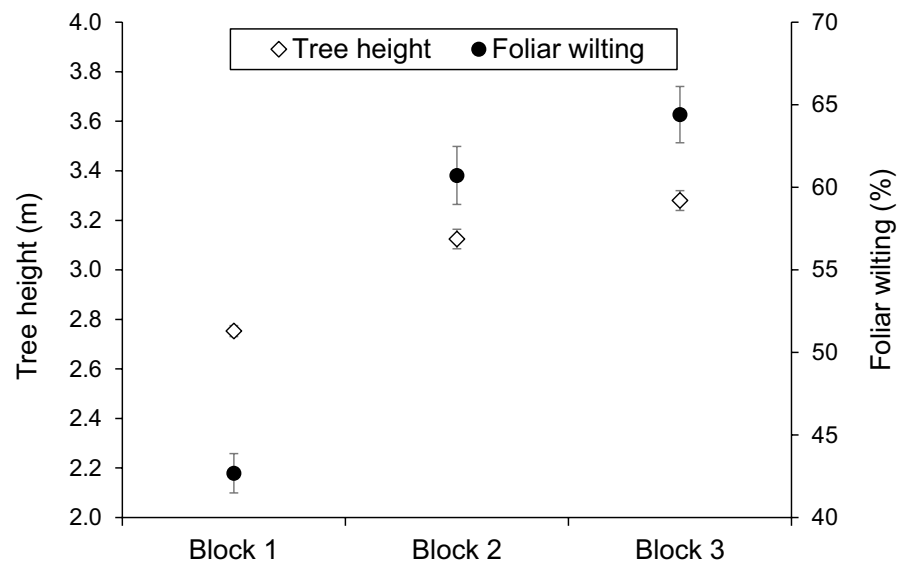

Fig. 6 Mean tree height and leaf wilting symptoms shown by 160 U. minor progenies planted in an experimental plot at Puerta de Hierro Forest Breeding Center (Madrid, Spain). The plot included 2492 plants in an area of $1265 \mathrm{~m}^{2}$, and was divided in three blocks with a completely randomized design. Trees were inoculated with $O$. novo-ulmi in two consecutive years (2014 and 2015) at the age of 4 and 5 years. Tree height was measured the year before inoculation. Leaf wilting values correspond to 60 days after the second inoculation (vertical bars are standard errors). Note the low height of trees and the reduced symptoms in Block 1, as compared with Blocks 2 and 3. Block 1 had a background of more intensive cultivation, possibly resulting in nutrient deficiency 


\section{Sourcing the pathogen for elm screening}

\section{Ongoing evolution of the pathogen populations}

In elm breeding, two key requirements are the selection of pathogen isolates for performing artificial inoculations and a good understanding of the pathogen and vector populations against which resistant elms are to be deployed. However DED is not caused by a single pathogen species, nor is it spread by a single species of vector, and the two introduced pathogen species, $O$. ulmi and $O$. novo-ulmi, have been in a highly unusual state of evolutionary flux because of extinction, hybridization events, and changes in selection pressures as the epidemics have progressed. Therefore it is desirable, when screening for resistance, to have an awareness of both past and current developments in a very dynamic and changing DED situation.

The importance of monitoring pathogen populations is emphasised by the arrival of $O$. novo-ulmi in the 1940s, which has resulted in the steady replacement and now near extinction of $O$. ulmi across Europe and North America. O. ulmi and O. novo-ulmi are differently adapted. O. ulmi is a relatively weak pathogen of European elms, has a slow growth rate at $20{ }^{\circ} \mathrm{C}$ but grows fast at $30{ }^{\circ} \mathrm{C}$. O. novo-ulmi is aggressive on European elms, fast growing at $20^{\circ} \mathrm{C}$ but slow growing at $30{ }^{\circ} \mathrm{C}$ (Brasier 1986a; 1991). Both species were probably introduced from East Asia. The first elm breeding programme, aimed at producing elms resistant to $O$. ulmi, was initiated by Dutch pathologists Christine Buisman and Johanna Westerdijk in the Netherlands in 1928 (Mittempergher and Santini 2004). However the programme was undermined by the discovery of a new 'aggresssive strain' of the pathogen, later designated O. novo-ulmi (Gibbs et al. 1972; Gibbs and Brasier 1973; Brasier 1991 ) and was re-orientated in the 1970 s by screening the products against $O$. novo-ulmi. Because $O$. ulmi is a weaker pathogen and is now largely extinct in many locations it is no longer essential to use it in resistance screening. However, used in comparison with $O$. novo-ulmi it should still provide important clues to the genetic and physiological mechanisms of pathogenicity and resistance. It is therefore important that it is properly conserved in culture collections.

O. novo-ulmi itself is not a single entity but has spread as two subspecies: subsp. americana (SSAM) in North America and subsp. novo-ulmi (SSNU) in Europe and Central Asia. Among their multiple differences, SSAM is on average more aggressive to elms and faster growing than SSNU and has morphologically different perithecia (Brasier 1986b; Brasier and Kirk 1991). Furthermore, SSAM also exhibits a distinct substructure. The vegetative compatibility (vc) system (self -non-self recognition system) of O. novo-ulmi is central to the organisation of its populations (Brasier 1986a). Surveys across North America have shown that two near clonal vc and molecular lineages, designated AMSG and EUSG, comprise $>60 \%$ of the SSAM population, alongside a genetically highly heterogeneous component including probable SSAM $\times$ EUSG recombinants (Brasier 1996; Brasier \& Kirk 2000). No differences in growth rate or pathogenicity were found between SSAM, EUSG or the heterogeneous component. In the 1960-70s elements of this SSAM population were introduced to western Europe, where a Spanish survey demonstrated two divergent molecular groups within SSAM, designated Ona Groups 1 and 2 (Solla et al. 2008). A recent genome-wide study of the DED pathogens has also identified two genetically distinct lineages within SSAM, labelled AME1 and AME2 (Hessenauer et al. 2020). Isolates in common to the studies indicate Ona 1 and AME1 correspond to the EUSG and its closer genetic derivatives, and Ona 2 and AME2 to the AMSG and its derivatives. Isolates 
belonging to AME1 exhibit faster mycelial growth in vitro and higher divergence in genes overexpressed during the yeast phase (Nigg and Bernier 2016) compared to AME2 isolates (Hessenauer et al. 2020).

Whether migrating as SSAM or SSNU, O. novo-ulmi has evolved rapidly through hybridization, introgression and selection since the 1940s (Brasier 2001; Brasier et al. 2004). In this, O. ulmi initially played a critical role. During its replacement by $O$. novoulmi transient, largely unfit hybrids were formed (Kile and Brasier 1990; Brasier et al. 1998) via which $O$. novo-ulmi acquired $O$. ulmi loci including the MAT-1 mating type locus, vc (vic) loci (Paoletti et al. 2006), pathogenicity loci (Et-Touil et al. 1999) and temperature response loci (Brasier et al. 1998; Et-Touil et al. 2019; Hessenauer et al. 2020). As a result $O$. novo-ulmi populations migrating across Europe changed rapidly from being largely clonal to highly genetically heterogeneous in just a few years, including Portugal and Spain (Brasier 1988; Brasier and Kirk 1991; Brasier et al. 2004). Many genes acquired from $O$. ulmi were soon lost, but the O. ulmi MAT-1 and vic loci became fixed in $O$. novoulmi populations (under selection pressure from deleterious RNA viruses) and $O$. novoulmi now carries O. ulmi MAT-1 and vic loci almost by definition (Brasier 2001). In North America a similar but much slower introgression-driven evolution of $O$. novo-ulmi SSAM has also occurred. This has included the long term survival of the dominant AMSG and EUSG near-clones. Their continued dominance could be due to the high susceptibility of $U$. americana, low virus pressure, their competitiveness in the saprotrophic phase, and the low diversity of O. ulmi in North America (Brasier and Kirk 2000).

Furthermore, as a result of the geographical overlap of the two O. novo-ulmi subspecies SSAM and SSNU in Europe since the 1970s, swarms of SSAM $\times$ SSNU hybrids have occurred freely in the overlap zones (Brasier 2001; Santini et al. 2005b; Solla et al. 2008; Brasier and Kirk 2010; Hessenauer et al. 2020). By the 1980s more than $70 \%$ of the $O$. novo-ulmi population at sites in the Netherlands and Italy were SSAM $\times$ SSNU hybrids. The hybrids exhibit novel $O$. novo-ulmi phenotypes, and as a result of selection, locally adapted genotypes may be emerging (Brasier et al 2021). O. novo-ulmi is, once again, reinventing itself in Europe.

The complexity and dynamics of the above events again emphasises the need for continued monitoring of changes in the pathogen populations across Europe, Central Asia and North America.

\section{Selection of isolates for resistance screening}

Against this background, what isolates should be used for resistance screening? It is scientifically desirable, but not essential, to understand what form of $O$. novo-ulmi is present in the vicinity in which the material will be released. In North America this is likely to be 'pure' SSAM, although this population is nonetheless intrinsically variable as confirmed by the occurrence of two genetic lineages in this subspecies (Brasier and Kirk 2000; Solla et al. 2008; Hessenauer et al. 2020). In eastern Europe and central Asia it is likely to be 'pure' SSNU, also variable (Brasier 1986b). In Western Europe there is an increasingly complicated SSAM $\times$ SSNU hybrid situation (cf. Brasier and Kirk 2010). Nonetheless several lines of evidence argue for simply using the most aggressive O. novo-ulmi genotypes available locally for screening. First, even in 'pure SSNU' populations some highly pathogenic genotypes of SSNU are present, an example being SSNU isolate H327 widely used as a standard in pathogenicity comparisons (cf. Brasier 1987; Et-Touil et al. 1999). Second, within O. novo-ulmi (SSAM or SSNU) inheritance of aggressiveness appears to be largely 
additive (multiple genes of small effect). Thus there was no evidence from crosses between moderately aggressive $(\mathrm{M})$ and highly aggressive $(\mathrm{H})$ O. novo-ulmi isolates for the segregation of major genes in the pathogen (Fig. 7a, b; Brasier 1987). An exception were the progenies of high $\times$ low and medium $\times$ low aggressiveness crosses, which segregated 1:1 (Fig. 7 c, d; Brasier 1987). This was later shown to be due to an introgressed O. ulmi pathogenicity gene in the low aggressiveness isolate (Et-Touil et al. 1999).

Third, as already mentioned, when $O$. novo-ulmi isolates of statistically different levels of aggressiveness are inoculated into the same $U$. procera clone across many seasons, they typically retain the same ranking order in terms of \% defoliation (Fig. 3), another indication that the pathogen $\times$ host interaction involves multiple, largely additive pathogenicity genes. Fourth, there is evidence that in the current post-epidemic period (with often very large numbers of small recruitment elms, infection levels periodically high and (in Europe) often smaller less effective vectors predominating) the most aggressive pathogen genotypes are being favoured, probably as a result of directional selection for higher aggressiveness (Brasier and Webber 2019). Also, the SSAM $\times$ SSNU hybrids now emerging widely in Europe are significantly more pathogenic than their

Fig. 7 The heritability of pathogenic aggressiveness in $O$. novo-ulmi SSNU. Top line, the \% defoliation of clonal $U$. procera caused by isolates of typically high, $(\mathrm{H})$, typically medium (M), and exceptionally low (L) aggressiveness. a-d Pathogenicity distributions of progenies from crosses. Crosses a $\mathrm{H}^{1} \times \mathrm{H}^{2}$ and $\mathbf{b} \mathbf{M} \times \mathrm{H}^{1}$ show largely additive variation in aggressiveness. Crosses $\mathbf{c}$ and $\mathbf{d}$, between $\mathrm{H}^{2}$ and $\mathrm{M}$ and $\mathrm{L}$, the isolate with unusually low aggressiveness, show segregation of a single gene. The isolate involved (AST27), from an epidemic front site in Iran, was subsequently shown to be carrying a single introgressed O. ulmi pathogenicity gene (EtTouil et al. 1999). Adapted from Brasier (1987)

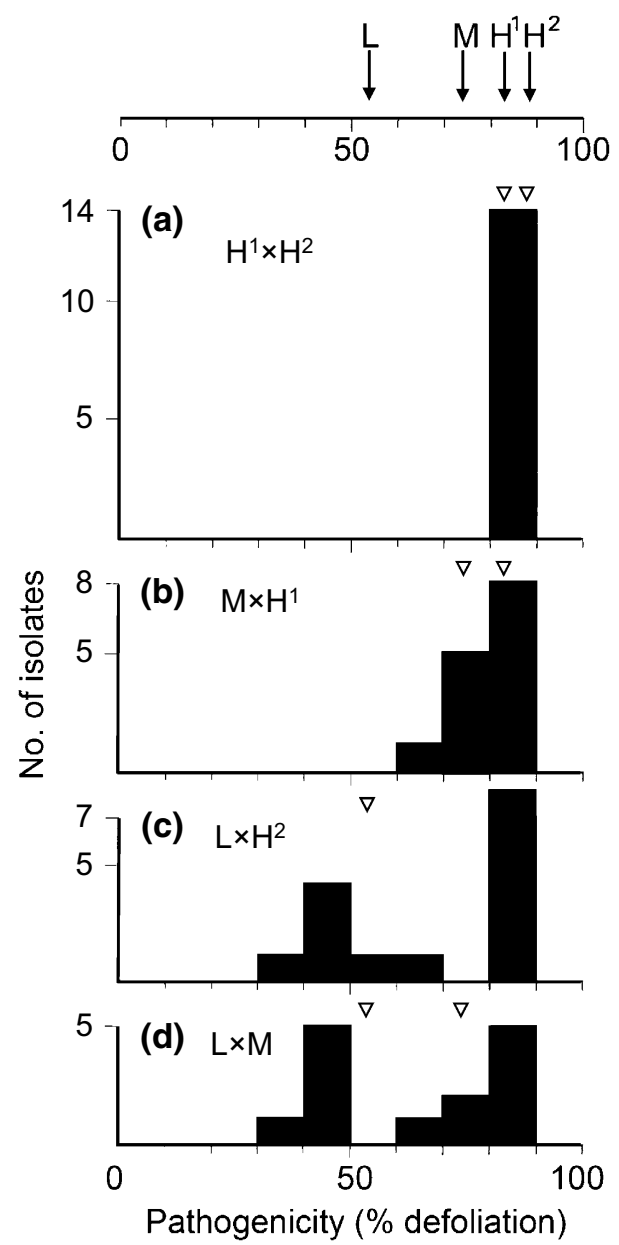


SSNU parent and just as highly pathogenic as SSAM, again probably due to directional selection (Brasier and Kirk 2010; Brasier et al 2021). Taking all the above factors into account, $O$. novo-ulmi isolates of suitably high aggressiveness are likely to be available for screening in most locations.

A related question is during what phase of the DED cycle is it best to collect isolates for elm screening: from beetle feeding wounds, infected xylem, or the bark (or phloem) of diseased elms? There are in fact two pathogen cycles in DED (Webber and Brasier 1984). The pathogen's saprotrophic phase-or 'bark to bark phase' — when it lives in and around the beetle breeding galleries in dying elm bark (Fig. 2a), is the main gene pool of the pathogen. The beetles carry spores of the pathogen from the bark to bark continually across the years, and it is during this phase that the pathogen is at its most active and abundant: sexual recombination takes place, a turnover of genotypes occurs (via competitive growth and vegetative incompatibility interactions), and RNA viruses spread between the mycelia (Brasier 1986c; Webber et al. 1988). For this reason, the saprotrophic phase is best avoided when collecting isolates solely for screening.

The other pathogen cycle in DED is the pathogenic phase (Fig. 2b-d), which begins when the pathogen grows in a feeding wound and enters the xylem, causing the foliar wilt. This phase is in reality just a side loop from the bark to bark cycle. Nonetheless, it is also the phase where strong selection for pathogenic ability, including ability to colonise the feeding wound and ability to spread in the xylem, will occur; and the phase in which deleterious virus infections are probably lost. Experiments have shown that the putatively fitter genotypes from the pathogenic phase can pass back into the main gene pool in the bark: a genetic feedback loop (Webber et al. 1988). Essentially the pathogenic phase is a genetic sieve. The potential difference between the pathogenic and saprotrophic phase gene pools can be seen in Fig. 8, which compares pathogenic and saprotrophic phase isolates collected from the same disease site (Brasier and Webber 1987). Only the pathogenic phase isolates showed a clear correlation between growth rate and pathogenicity. The saprotrophic phase isolates did not: they were altogether

Fig. 8 Pathogenicity versus growth relationships of $O$. novoulmi SSAM isolates sampled from the pathogenic phase in xylem (open circle) and the saprotrophic phase in the bark around beetle galleries (filled circle) at the same disease site in Britain. Only the pathogenic phase isolates showed a correlation between these two key fitness parameters $(r=0.63)$. These isolates would have been subject to rigorous selection in the feeding wound and in the xylem. Adapted from Brasier and Webber (1987)

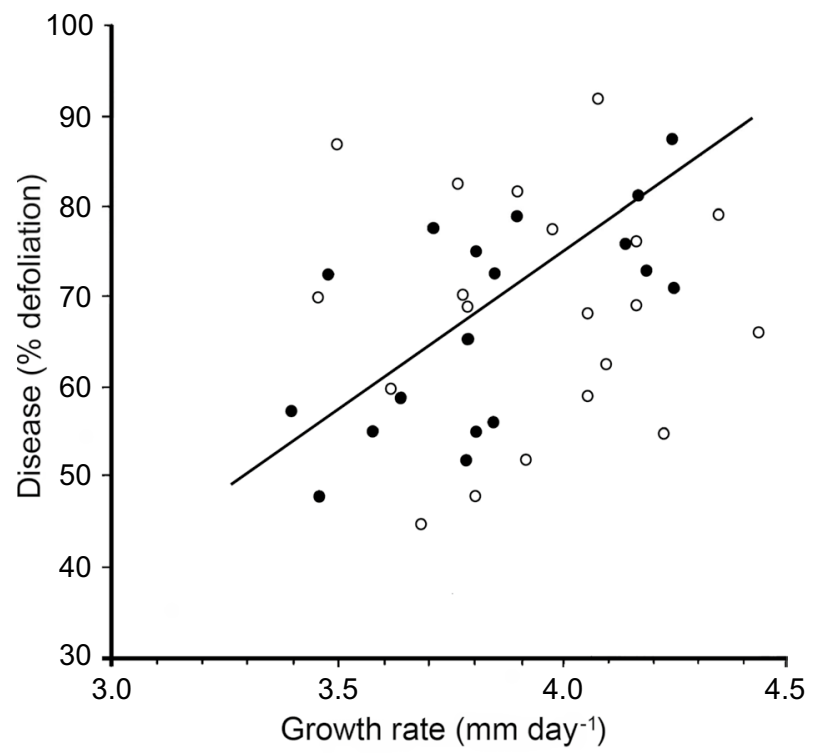


more variable. Therefore, because pathogenic phase isolates are on average likely to be fitter and more aggressive, due to host selection, collecting cultures for screening from the xylem of trees with advanced wilt symptoms is recommended.

Note that it is probably the feedback loop from the pathogenic phase to the saprotrophic phase (Fig. 2) that facilitates any directional selection for $O$. novo-ulmi aggressiveness in the current, post epidemic period. This raises the issue of the likely impact on $O$. novoulmi populations of any deployment of resistant elms. When deployed in small numbers (relative to nearby susceptible elms) they will probably exert only limited selection on a local $O$. novo-ulmi population. Were they to be deployed in large numbers and some local O. novo-ulmi genotypes infected the xylem and caused dieback, it is theoretically possible that a gradual increase in pathogen aggressiveness might occur via the feedback loop. On present evidence, however, this appears unlikely. First it appears that in the current post epidemic period $O$. novo-ulmi may already be close to its maximum pathogenic aggressiveness (Brasier and Webber 2019; Brasier et al 2021). Second, any further increase in pathogenic fitness will probably be set against the need to maintain growth, reproductive and general competitive fitness in the saprotrophic phase and then successfully re-infest the next generation of emerging beetles (Webber and Brasier 1984; Brasier 1986a).

Even the sexual compatibility type (or mating type) of an O. novo-ulmi isolate can influence its pathogenicity. On average, MAT-1 types are slightly less pathogenic (and slower growing) than MAT-2 types on U. procera, but this difference is not detectable in all tests due to seasonal variations in host susceptibility. Also some MAT- 1 isolates, including H327 (see above), are just as pathogenic as MAT-2 s. This trend is probably due to MAT-1 s tending to be significantly more fecund than MAT-2 s (Brasier 1986a) and therefore more specialised in sexual reproduction: a division of labour. In one test (Fig. 9) an extreme difference between pathogenicity of MAT-1 s and MAT-2 s was detected among wild isolates

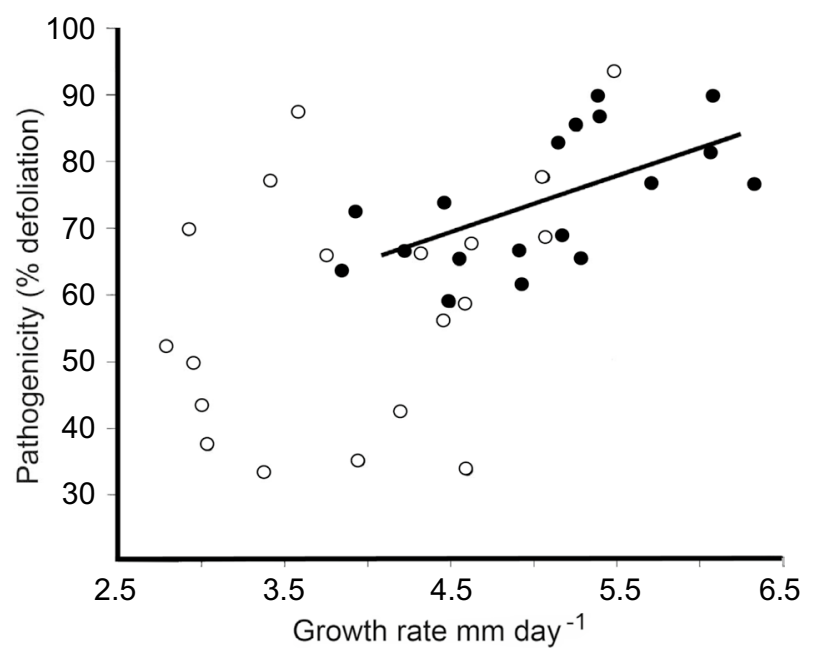

Fig. 9 Pathogenicity versus growth relationships of O. novo-ulmi SSAM isolates of different mating types, MAT-1 (open circle) and MAT-2 (filled circle) from the early epidemic stage in Britain. Only the MAT-2 isolates showed a correlation between the two fitness parameters $(r=0.57)$. Adapted from Brasier and Webber (1987). Note that the MAT-1 isolates were on average slower growing and less pathogenic than the MAT-2 types. This is probably because some of them carried not only a recently introgressed $O$. ulmi MAT-1 locus but some other introgressed O. ulmi genes (Brasier 2001); and because MAT-1 s tend to be specialised for sexual reproduction (Brasier 1986a) 
and progeny of MAT- $1 \times M A T-2$ crosses (Brasier and Webber 1987). In this case only the $M A T-2 \mathrm{~s}$ showed a correlation between pathogenicity and growth rate. The isolates came from the early epidemic period when $O$. ulmi was in decline. The result was probably due to the MAT- 1 isolates having arisen de novo via introgression of the MAT- 1 locus from $O$. ulmi; and to their still carrying other $O$. ulmi genes of relatively strong and negative effect on their pathogenicity and growth. In most present day, European, post-epidemic $O$. novo-ulmi populations the more 'negative' $O$. ulmi genes have probably been eliminated by selection. Therefore it may be less necessary now, in the post epidemic period, to know the mating type of an $O$. novo-ulmi isolate used in resistance screening. Nonetheless it is always valuable to have as much scientific information on the pathogen genotypes used as on the host.

Often, probably only a single genotype infects the xylem from a beetle feeding wound. However there have been suggestions to use mixtures of pathogen isolates in elm screening. This may sometimes reflect a degree of uncertainty about the quality of the inoculum. For instance, in the frame of the Italian elm breeding program a mixture of one isolate per each of the two O. novo-ulmi subspecies was used to challenge candidate clones (Santini et al. 2008). Elm trials in North America have sometimes used a mixture of $O$. ulmi and O. novo-ulmi isolates (Townsend et al. 1995; Smalley and Guries 1993; Pinchot et al. 2017), possibly because the high susceptibility of $U$. americana results in smaller differences in aggressiveness between the two species. However an argument can be made that $O$. $u l m i+O$. novo-ulmi species mixtures should be avoided because of the possibility of induced resistance to O. ulmi (Scheffer et al. 1980; Solla and Gil 2001a; Hubbes 2004), especially in moderately resistant European elms, although some studies have found little effective response (Sutherland et al. 1995). Mixtures of O. novo-ulmi genotypes are likely to compete numerically and perhaps qualitatively as budding yeasts in the xylem vessels. They may also compete in growth rate, and via antagonistic vegetative compatibility reactions, when growing as hyphae across vessel end walls. Mixtures of MAT-1 and MAT-2 mating types should probably also be avoided because they are programmed to interact sexually. Therefore without strong experimental evidence for a greater efficacy of isolate mixtures in screening, including over multiple seasons, and why, they are probably best avoided. Statistically sound scientific data on the behaviour of elm varieties and genotypes may best come from inoculating them with a single, well characterised pathogen genotype (e.g., Martín et al. 2015).

Finally, assessment of pathogen aggressiveness should preferably be undertaken by inoculating elms older than 3 years (Solla et al. 2005c), although early screening tests using young plantlets have been also developed (Green et al. 1985; Martín et al. 2019b).

\section{Handling and conservation of pathogen isolates}

While the use of pathogen reference isolates with demonstrated high aggressiveness in previous screening tests is recommended (Santini et al. 2005a; Buiteveld et al. 2015) it should also be noted that without careful handling isolates of both $O$. novo-ulmi and $O$. ulmi easily degenerate in artificial culture, probably due to stress effects. This is usually manifested as sectoring and/or a change from the original wild type pattern to a variety of more densely-mycelial, sometimes pigmented, non-wild type forms (Fig. 10). Cultures in institutional culture collections, unless stored under very specific conditions (e.g. stored at $-80{ }^{\circ} \mathrm{C}$, a reasonable guarantee of genetic stability), are often degenerate and unsuitable for study, including altered pathogenicity to elm. Many were probably degenerate before 


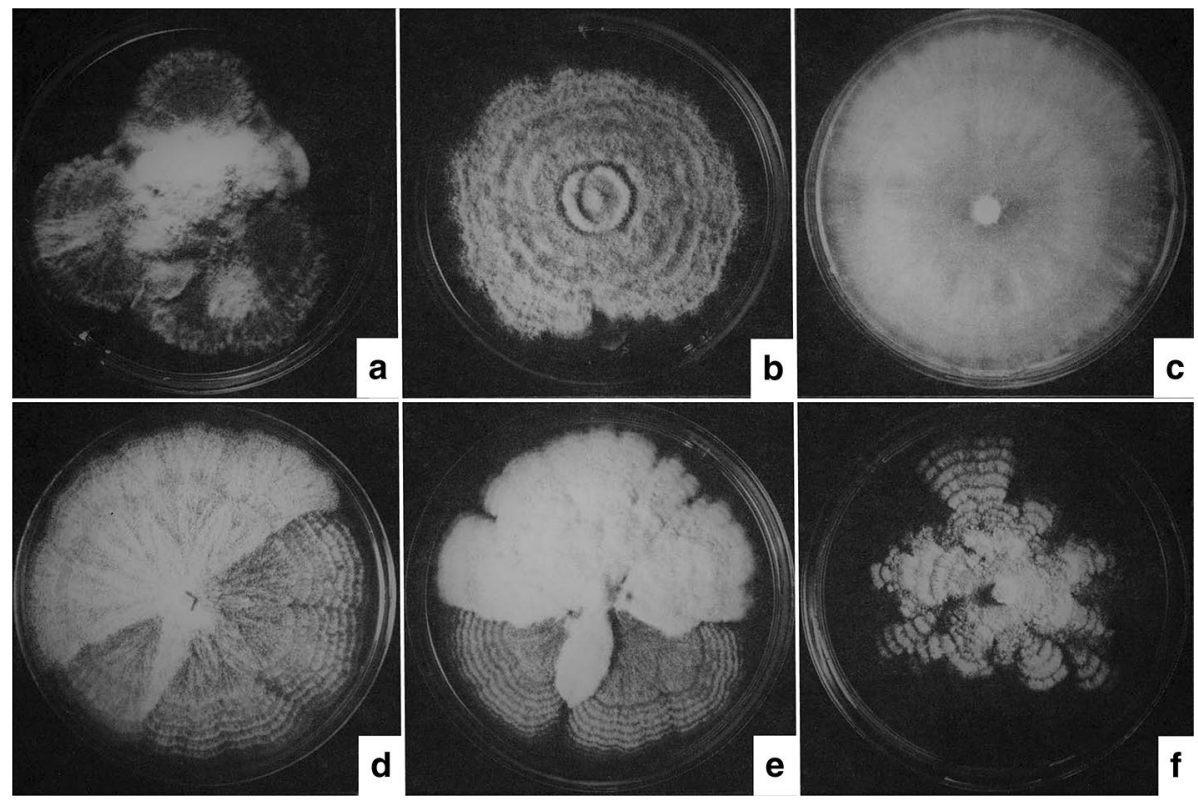

Fig. 10 Examples of degenerate cultures of the pathogens. a A culture of O. novo-ulmi SSAM severely degenerated after storage under mineral oil. b, c Common degenerate forms of $O$. ulmi. d An O. novo-ulmi SSAM wild-type colony (lower part) giving rise to a more densely mycelial non wild-type sector (above). e An example of a commonly seen dense, felty non wild-type sector (upper part; in this case arising in a rare O.novo-ulmi isolate carrying introgressed $O$. ulmi genes). f, The unstable 'amoeboid' colony type that occurs naturally with severely virus-infected isolates of $O$. novo-ulmi. The cultures shown in a-e are all laboratory artifacts and are not normally found among fresh wild isolates. Adapted from Brasier (1982)

being stored. Some authors working on $O$. ulmi in the 1930-60 s were unwittingly describing degenerate isolates. The same applied to O. novo-ulmi in the 1970s. If the same isolate is to be used for screening over several years, therefore, taking sub-cultures from altered sectors of growth, or from cultures that are old or drying out, should be avoided. Rather than risking this problem it may be better to collect fresh local cultures annually during late winter or early spring from xylem of elms (whether naturally infected or inoculated) that were heavily diseased in the previous season. Alternatively the original wild type colony pattern of an isolate should be noted (perhaps recorded photographically) and probably reconfirmed annually. During screening, as well as the selected isolate, other isolates of known aggressiveness can be tested as controls, ideally using a moderately susceptible host. For methods of isolation and culture maintenance see e.g. Brasier (1981).

\section{Pathogen inoculation protocols, and the implications of vector feeding behaviour, for elm screening}

Methods used to inoculate elms with the pathogen include making pinpricks in the young shoots high in the crown (H.S. McNabb method, Iowa State); making small cuts with a scalpel in 2 year old twigs no more than one fifth of the way down the crown's height (e.g. Tchernoff 1965, method 6; Gibbs et al. 1972); making a 4-mm-deep hole one-half $\mathrm{m}$ from the ground and injecting a spore suspension into the hole (Beier et al. 2017b); 
inoculating bark cores 8-10 cm above soil level (e.g., Solla and Gil 2002b); and inoculating root flares via a 0.5 inch borehole (e.g. Pinchot et al. 2017). The pinprick method aims to more closely mimic the mode of pathogen entry via a beetle feeding wound, and the 'one fifth down the crown' method somewhat the same, the rationale being that when an infection is initiated via a feeding wound the pathogen has to spread downwards against the sap-stream from the infection site. Inoculation near the base of a tree is probably more equivalent to the transmission that occurs via root grafts between adjacent diseased and healthy trees. In nature, this can lead to a more rapid and extensive collapse of the crown. As there is probably no one ideal method, when testing promising resistant elm material an argument can be made to use both (1) a more delicate 'within the high crown' inoculation to mimic natural field exposure of the material; and (2) a more robust basal inoculation test that should put the material under the strongest possible pathogen pressure.

In this regard, the numbers of spores used to infect elms during screening is usually of the order of $\sim 500,000$ (ie. $5 \times 10^{5}$ ). This figure is at the high end of the numbers reported to be carried by scolytid beetles. The species of Scolytus involved in disease transmission vary in size, carry different average spore loads of the pathogen, and tend to breed in elms of different bark thickness (Webber and Brasier 1984; Webber 2004). They therefore vary in their likelihood of initiating an infection. They also vary in their relative frequency during and after an epidemic, and therefore in their potential to influence current disease levels. A method for estimating the numbers of spores required for xylem infection, using artificial 'beetles' and creating wounds in twig crotches similar to feeding wounds, showed that at ambient humidity around 1000 spores were needed to infect $U$. procera (Webber $1987,2004)$. Xylem infection frequency at 1000 spores was around $20 \%$, rising to $40 \%$ with 50,000 spores.

In parallel studies the number of spores carried by the larger European elm bark beetle $S$. scolytus under UK conditions averaged 50,000, with an upper level of $\sim 700,000$; whereas those carried by the smaller European elm bark beetle $S$. multistriatus averaged $<200$ spores with an upper level of 200,000 (Webber and Brasier 1984). S. multistriatus emerging from breeding material in Spain in summer carried a similar number of spores, but the much smaller S. kirshii from the same elm material almost no spores (Webber 1990). However the number of spores carried will also vary according to the position of the pupal chambers, bark moisture, bark thickness, and the season of emergence (Webber and Brasier 1984; Faccoli and Battisti 1997). Thus in Italy over half of the individuals of S. multistriatus and of the very small $S$. pygmaeus emerging in spring carried the pathogen, whereas in summer less than $10 \%$ of the beetles did so (Faccoli and Battisti 1997).

Broadly DED is all about the interaction of the host, pathogen and vector populations: it is a multiple host-multiple pathogen and fungal virus-multiple vector system in which critical thresholds often lead to either explosive or quiescent disease (Webber and Brasier 1984). In the current post epidemic period in Europe, with large numbers of mainly small elms under cyclical attack, $S$. scolytus is at a disadvantage due to a shortage of suitable sized breeding material and $S$. multistriatus and other smaller vectors are more significant in disease transmission (Brasier and Webber 2019). Further, in the absence of S. scolytus, $S$. multistriatus and smaller vectors may sometimes have access to thicker bark for breeding than they had during the main epidemic, and so carry more spores. If large elms of moderate resistance begin to dominate the landscape again in future a resurgence of $\mathrm{S}$. scolytus is likely. Whether this might also occur if large numbers of highly resistant elms were deployed is unclear, but an increase in the $S$. scolytus population would probably accelerate any evolution, via the feedback loop (Fig. 2), towards increased aggressiveness in $O$. novo-ulmi. 
Considering that resistant elm material needs to be useful for tens if not hundreds of years, by concentrating breeding and selection almost entirely on resistance to the pathogen in the xylem we may be overlooking other useable aspects of host resistance, including beetle feeding preference and resistance in the beetle feeding wound. Thus the 'main' European vector, $S$. scolytus, shows host species feeding preferences. It preferentially feeds on $U$. procera or $U$. minor rather than either U. glabra or U. laevis (Webber and Kirby 1983; Webber 2000; Sachetti et al. 1990), yet both U. glabra and U. laevis are more susceptible than U. procera on inoculation (Brasier 1977).

Resistance to the pathogen is not confined to the xylem. Differential resistance to the pathogen has been demonstrated in the bark (phloem) of feeding wounds. When artificial feeding wounds in $U$. pumila were infected with 10,000 O. novo ulmi spores $70 \%$ resulted in xylem infection, but without any external symptoms (Webber and Brasier 1994). On the moderately resistant Commelin elm (a complex U. minor $\times$ U. glabra hybrid; Heybroek 1993) 10,000 spores resulted in only $30 \%$ xylem infection, though some external symptoms developed. In $U$. procera the xylem infection levels were $\sim 70 \%$ i.e. similar to $U$. pumila, and external symptoms were always observed. The minimum spore thresholds resulting in infection of $U$. pumila, Commelin and $U$. procera were 500, 1000 and 500 spores respectively. Apparently the immunity of $U$. pumila to DED does not preclude successful entry by the pathogen. It also appears that Commelin elm may have an active resistance mechanism in the bark around the feeding groove (and maybe in the bark elsewhere in the tree). The possibility that this resistance is derived from its $U$. glabra parentage needs investigation (Webber and Brasier 1994). Combining resistance to beetle feeding and the infection process with xylem resistance in elms might considerably enhance their field performance.

It should be noted that the feeding wound is also the stage during which the pathogens' RNA viruses or d-factors have most effect. By reducing spore viability and growth rate of $O$. novo-ulmi (and O. ulmi) in the feeding wound the more deleterious viruses can significantly reduce or prevent xylem infection (Brasier 1983; 1986a; Webber 1987; 1993; Sutherland and Brasier 1997). By exerting a degree of biological control, they may have contributed to the unexpected decline of the first DED pandemic in Europe (Brasier and Webber 2019). Early in the second epidemic in Europe the viruses spread readily in the $O$. novo-ulmi clones at epidemic fronts and might have supressed this epidemic if $O$. novoulmi had not acquired the MAT-1 and vic genes from $O$. ulmi, increasing its resistance the viruses (Brasier 2000b). The existence of what appears to be a single clone of O. novo-ulmi SSAM in New Zealand still offers an opportunity for biological control of the pathogen by deploying viruses (Brasier 2000b).

\section{Introgression of genes from susceptible and exotic elms into resistant cultivars}

When resistant elm cultivars are introduced into the field, uncertainty may exist about their long-term performance and that of any outcrossed progeny produced later. If the cultivars have outstanding DED resistance and low phenotypic plasticity for this trait, the short-term impact of DED in the planting area should be low or negligible. As resistance to DED has a high level of additive genetic control (Solla et al. 2015), the progeny of fertilisation within the planted cultivars can also be expected to show a high level of resistance. However, there is also the possibility of out-crossing between the resistant cultivars and local, surviving susceptible elms. This risk is enhanced by the dispersal distances of elm pollen (up 
to $8 \mathrm{~km}$ in $U$. minor) (Bertolasi et al. 2015). Although in Europe most susceptible mature elms have been killed by DED, abundant small elms still survive as seedlings, sprouts and root suckers (Brasier 1986a; Nielsen and Kjær 2010; Brasier and Webber 2019). In years of low disease incidence, these flowering, small surviving elms will sustain gene flow between isolated trees and stands. In some cases, mature elm trees also survive in certain locations (Bertolasi et al. 2015; Martín et al. 2006). For instance, a considerable number of large individuals of the Atinian elm (U. procera) still survive in Spain despite the high susceptibility of this cultivar to $O$. novo-ulmi, possibly due to environmental resistance (Martín et al. 2006). Since Roman times, this cultivar was massively propagated and planted in the Iberian Peninsula and England, and served as living support of the grapevines (Gil et al. 2004), among other uses. The genotypic diversity of field elm in these regions was dominated by this single cultivar, which could have had consequences for the fast pathogen spread in epidemic fronts (Martín et al. 2010c). The survival of susceptible trees implies that the long-term resistance of the progeny of resistant cultivars may be reduced where susceptible elms occur in sympatry with the introduced population. Indeed, recent research has shown that in resistant $\times$ susceptible progenies DED resistance can be overcome by recurrent infections (Martín et al. 2021).

Another concern for resistant material is the risk of genetic introgression from introduced exotic species or from hybrids (Fig. 11). This risk is particularly high with regard to the spread of the Siberian elm (U. pumila), which was introduced into Spain in the sixteenth century (Cogolludo-Agustín et al. 2000) and in the USA from about 1900 (Zalapa et al. 2009) as an ornamental, and into Italy in the 1930s, at the time of the first DED epidemic, to replace the lost elms, which, were widely used in agriculture (Brunet et al. 2013). In all these countries $U$. pumila has shown high reproductive potential, and a tendency to

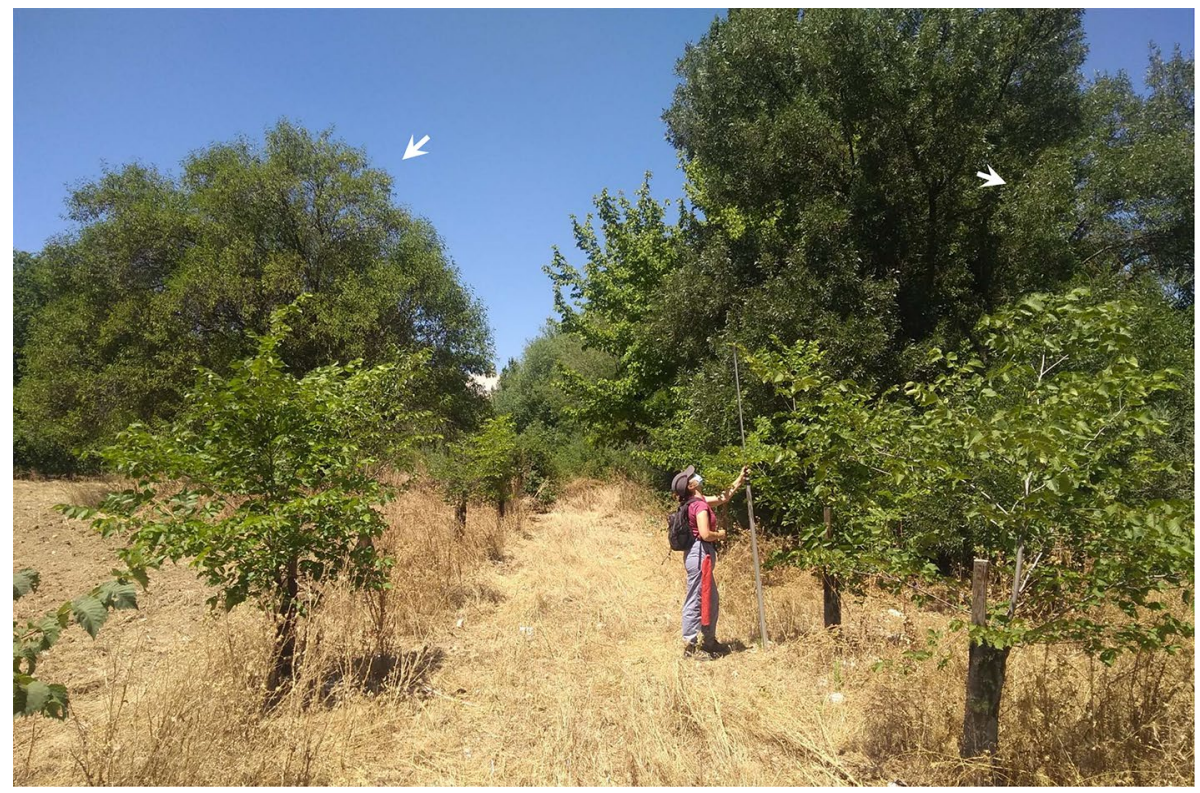

Fig. 11 Plantation of native Ulmus minor trees on a plain area of the Meaques stream (Madrid, Spain). The presence of exotic Siberian elms near the plantation (arrows) will probably threaten the native germplasm of future elm generations in the area 
high hybridization rates, traits that may increase the potential for invasiveness (Ellstrand and Schierenbeck 2000). Indeed, it has been shown that Siberian elm readily hybridizes with U. minor in Europe (Cogolludo-Agustín et al. 2000; Brunet et al. 2013) and with U. rubra in the USA (Zalapa et al. 2009; Brunet et al. 2016), forming large hybrid populations. Siberian elm has, in general, moderate to high resistance to DED (Smalley and Guries 1993), and has therefore been used in several breeding programs as a source of resistance genes through backcrosses. However, conservation concerns in Spain have led to a prohibition of the marketing of $U$. pumila and its hybrids for use as a forest tree.

The ease of hybridization between $U$. pumila and $U$. minor led to questions about the native character of seven resistant $U$. minor cultivars selected by the Spanish elm breeding programme (Martín et al. 2015). Selected cultivars were identified based on their morphological characters as $U$. minor, but in some cases distinguishing any hybrids from native $U$. minor by morphology alone is very difficult. Preliminary results through single nucleotide polymorphism (SNP) marker analysis indicate that two out of the seven resistant elms may carry $U$. pumila genes (unpublished results). These two clones (Toledo and Fuente Umbría) have been provisionally withdrawn for use in natural forest habitats. Any new, putatively resistant $U$. minor cultivars are now being analysed with SNP markers to characterize their genetic background.

There are contrasting opinions about the deployment of hybrids or introgressants in natural areas and on their potential impact in elm reintroduction in the longer term. It could be argued that given that $U$. pumila and hybrids are already widespread in the landscape, resistant native cultivars used in restoration will inevitably outcross with $U$. pumila or elm hybrids in future, and that preventing such hybridization is not technically feasible. Such an argument is however, in contradiction to the aim of restoring the native species, given the potential invasiveness of the hybrids. From an ecological perspective, U. pumila is less tolerant of flooding than European elms (Heybroek 1979), and therefore introgression with $U$. pumila genes could reduce the average fitness of offspring of reintroduced U. minor in riparian areas. In this case, natural selection may favour the persistence of genotypes with native traits. Further, a positive outcome of such introgression could be a higher resistance to DED in the progeny (Solla et al. 2015; Pecori et al. 2017), or better adaptation to aridification resulting from climate change, since $U$. pumila is well adapted to semi-arid conditions (Heybroek 1979). Independently of these possibilities, the selection of planting areas should take into account the presence of exotic or susceptible elms in the area and the potential impact on the planted elms.

\section{Changes in the host microbiome}

In recent decades, it has become increasingly apparent that the response of plants to external stress factors is strongly influenced by their symbiotic microbiome. The microbiome structure presents an additional component to be considered in plant breeding programs (Wei and Jousset 2017). In particular, microorganisms inhabiting the rhizosphere, phyllosphere and the internal tissues of leaves, roots and stems (endophytes) have been shown to play a role in plant resistance against biotic and abiotic stress (Redman et al. 2011; Raghavendra and Newcombe 2013; Witzell et al. 2014; Busby et al. 2016; Terhonen et al. 2019). Although the underlying mechanisms are far from understood, variation in host microbiomes across environments may contribute to phenotypic plasticity in resistance traits. 
A bark endophyte of $U$. glabra, the ascomycete Phomopsis oblonga, significantly lowers the transmission rate of DED by competing with and limiting the breeding and development of elm bark beetles in U. glabra (Webber 1981; Dvořák et al. 2012). Some bacterial and fungal isolates artificially inoculated into the xylem of elm trees have also been found to enhance DED resistance (Lam et al. 1987; Bernier et al. 1996; Scheffer et al. 2008; Martínez-Arias et al. 2021). However, whether the natural host microbiome contributes to DED resistance under field conditions remains poorly understood. In recent years, the Spanish elm breeding programme has initiated a study of the potential associations between DED resistance and composition of the fungal endophyte flora in stem tissues. Using isolation and culturing the frequency and diversity of fungal endophytes was compared between 10 elm genotypes of varying resistance level to DED (Martín et al. 2013b). The study revealed that resistant clones tended to harbour a lower frequency and diversity of xylem endophytes compared to susceptible trees. Therefore, the possibility that use of resistant elms in forest restoration might have an unintended effect on the diversity of fungi colonizing xylem tissues deserves further research. Subsequently, a metabarcoding study on the same elm genotypes detected around twelve times more endophytic fungal taxa (213 OTUs) than the culture-based approach. No relationship between DED resistance and fungal diversity estimates in stem tissues (xylem plus internal bark tissues) was detected. However, the relative abundance of two orders of endophytic fungal yeasts (Chaetothyriales and Cystobasidiales) was correlated with the resistance of elm genotypes to DED (Macaya-Sanz et al. 2020). Functional traits of these yeasts are currently being investigated and, in preliminary tests, competitive mechanisms with O. novo-ulmi were observed (Martínez-Arias et al. 2021). The yeasts also improved root growth through production of IAA (Martínez-Arias et al.; unpublished results). This may be a mechanism through which the tree vigour is improved and survival of abiotic stress is enhanced. Indeed, although these observations were host genotype-dependent, they suggest that endophytic yeasts might influence plant homeostasis during stress, and therefore reinforce the defence response of resistant genotypes during infection.

The interaction of the local environment with the tree microbiome could be another factor underlying the variation in resistance to DED. Indeed, the stem fungal endobiome in $U$. minor appears to be strongly influenced by geographic location (Macaya-Sanz et al. 2020). Equally, however, a small proportion of the fungal endobiome appears ubiquitous across all environments (Macaya-Sanz et al. 2020). This highly stable core endobiome may have important functional roles in the ecophysiology of the host (Shade and Handelsman 2012).

Clearly the role of the elm microbiome needs further research. In particular, its possible contribution to DED resistance and the possibility that it could be managed to increase tolerance to DED in restoration plantations. Manipulation of the host microbiome would probably be more effective during the early developmental stages of seeds or seedlings, due to the priority effects that occur in endophytic microbial assemblages (Tosi et al. 2020). The effects of any such manipulation would need to be evaluated long term, not only with regard to DED resistance, but also to plant survival and growth in different environments.

\section{Other factors likely to affect plantations of resistant elms}

Unexpected mortality of elm trees may occur following mechanical coring with an increment borer. Six out of eight mature U. minor trees in Rivas-Vaciamadrid, Spain (Martín et al. 2006) died from internal spread of O. novo-ulmi the year after being cored, while 
adjacent non-cored trees remained asymptomatic (unpublished results). Following natural infection and recovery of the trees several years previously, the borer wound probably resulted in colonization and collapse of the current functional rings, allowing the pathogen to escape from previous radial compartmentalization. The literature indicates that risk of hardwood mortality caused by increment coring is low (Helcoski et al. 2019), but reports usually consider wounds as entries for fungi that accelerate wood decay, not as pathways of colonization when a vascular pathogen is inside a tree.

The emergence from neighbouring trees of beetles carrying spores of the pathogen early in the season, when moister bark may favour sporulation (Webber and Brasier 1984; Faccoli and Battisti, 1997), could be more unfavourable for newly established trees. If infection is combined with phloem girdling by the beetles and/or drought, young planted trees could fail. For this reason it is often recommended that young trees are planted at a lower density in zones at high risk from the pest or the pathogen (Woodcock et al. 2019). Mass trapping has been suggested as a method for reducing populations of Scolytus multistriatus (O'Callaghan and Fairhurst 1983; Paine et al. 1984), but is not recommended in plantations because of the risk of attracting beetles carrying the pathogen. The bark of elms under stress from causes other than DED is also attractive to breeding beetles (Baker and Norris 1968). Indeed, pruning wounds made on various species of healthy elms, including $U$. procera and $U$. americana, can significantly increase the number of beetles attracted to the trees (Byers et al. 1980; Landwehr et al. 1981). Severe pruning should therefore be avoided, particularly, during the temporal window of elm bark beetles flight (e.g., from April to October in Madrid, Spain; Solla et al. 2005b). Summer drought can also increase beetle pressure and contribute to tree failure, while high temperatures, and high light intensity and drought can supress foliar symptoms (cf. Sutherland et al 1997). During two hot dry years in southern Britain in 1975-6, at the local peak of the second epidemic, some avenues of mature elms showed no crown symptoms but, under resulting climate stress, were subject to girdling as a result of mass breeding attacks by $S$. scolytus. They also showed heavy xylem streaking due to the resulting colonisation by $O$. novo-ulmi.

In an elm plantation, several other circumstances may benefit the survival of trees. If a low pathogenic $O$. novo-ulmi strain (or $O$. ulmi) infects a moderately resistant tree and a certain threshold of foliage wilting is not exceeded, this tree will probably recover and will be less susceptible to further infections by O. novo-ulmi (Solla and Gil 2001b; Hubbes 2004). Furthermore, if sequential infection occur (i.e. in consecutive years), elm trees will have less chances of recovery compared with longer time periods between first and further infections (3 or more years; Solla and Gil 2001b).

There are still substantial gaps in our knowledge of the processes that regulate the beetle-fungus symbiosis as well as the vector-host tree relationship. The association between elm bark beetles and DED fungi depends on many factors, such as climatic and other environmental variables and the interactions between the different components of the biotic community. For example, many other organisms such as mites may play a role in the fertilisation and spread of the pathogen (Brasier 1978; Moser et al. 2010) while other fungi, bacteria and viruses can reduce the pathogen's survival potential through nutrient competition or parasitism (Webber and Hedger 1986; Webber 1993, Brasier 2000b; Pepori et al. 2018). Similarly, parasitism by fungi and nematodes influences the survival of the vectors. Such factors may yet have a role in the restoration of elms in the landscape.

Chemical communication is of potentially critical importance to the management of vector populations. Pheromone traps are already used to attract and detect the elm scolytids and it is known that chemicals attract the vectors to each other for aggregation and probably to the host for maturation feeding and breeding (e.g. Lanier et al. 1976, 1977; 
Grove 1983; Klimetzek and Kopp 1983). Chemical signals are also involved in the beetle feeding preferences. For instance, twig bark extracts from U. laevis and U. glabra induce less S. scolytus feeding than extracts from $U$. minor and $U$. pumila (Pajares et al. 2004). Similarly, bark extracts from certain $U$. minor genotypes induce less feeding activity than extracts from other genotypes of the same species (Pajares et al. 2004). Also, infection by O. novo-ulmi induces chemical changes in the elm that attract vectors to the trees for breeding (McLeod et al. 2005). The identification of any chemical compounds that make individual trees more attractive to beetles is of primary importance and could provide another avenue of marker-assisted breeding for native elm species (Pajares 2004; and $c f$. Büchel et al. 2016). Ultimately, integration of several, if not many different methods of DED control may be the most effective way forward.

\section{Unintended biosecurity breaches}

Epidemics caused by introductions of alien pests and pathogens are increasing in frequency as a result of growth in the international movement of plants (Brasier 2008; Santini et al. 2013). Good biosecurity is therefore important when moving elm material between centres, countries or between continents. Fortunately, being scolytid vectored, the DED pathogens are unlikely to be spread by movement of living elm plants, though their international movement via diseased elm logs or bark is well known (cf. Brasier and Gibbs 1973). Nonetheless it is likely that $O$. novo-ulmi SSNU was introduced to Uzbekistan (central Asia) in the 1970s by elm breeders working in Tashkent Botanic Garden, who inoculated elms with cultures brought from Volgograd (Russia). Probably only O. ulmi was present previously in central Asia.

The transport or introduction of living elm cuttings or saplings is, however, a much greater risk because of other non-native pests and pathogens they may harbour. In Britain alone, the elm yellows mycoplasma, the elm zig-zag sawfly and the apple root knot nematode (origin probably Japan) have all been introduced or detected in the past decade, and there is evidence that the nematode (EPPO 2017; Prior et al. 2019) and the mycoplasma were introduced on young rooted plants of resistant elms. The nematode is believed to have been imported to the Netherlands on elms from Japan for resistance breeding prior to World War II, and was subsequently distributed to at least ten other European countries on elm selections (EPPO 2017). The mycoplasma- infected stock in the UK was destroyed and the pathogen probably eradicated, but the sawfly and the nematode were already beyond effective control. Beyond this, there are other DED pathogens in Asia, including O. himalulmi on U. wallichiana in the Himalayas (Brasier and Mehrotra 1995) and another on Zelkova in Japan (Masuya and Brasier, in preparation) that could pose a threat to Eurasian and North American elms in future. It is therefore essential that strict biosecurity procedures are adopted, including if possible a year or more of quarantine and expert observation in the receiving country, when moving elm material across borders.

\section{Conclusions}

Complex environmental, biological and genetic factors can influence the behaviour of elm trees exposed to the DED pathogens and to their beetle vectors, potentially leading to uncertain or unintended outcomes during elm resistance testing and elm reintroductions. 
To avoid unwanted outcomes and to enhance long term elm durability in the context of changing pathogen, vector and disease pressures, a range of current and future actions are recommended:

- To evaluate the optimal geographical and climatic range of promising elm cultivars, tests for resistance to the pathogen should be undertaken over several years, and under contrasting climate and soil conditions (i.e. tests for host $\times$ pathogen $\times$ environment interactions). Ideally, tests should include abundant replication of target elms, and some more susceptible cultivars as controls.

- Resistant elm cultivars with a relatively uniform response to the pathogen across different environments should be deployed in locations where a wide range of environmental conditions are likely to be encountered. Cultivars with a high plasticity are likely to be useful only in locations which allow optimal resistance traits to be expressed.

- O. novo-ulmi isolates for use in artificial inoculations to test for resistance are probably best obtained locally, from xylem of heavily diseased trees. Any isolates older than 1 year should be checked to ensure no degeneration in culture has occurred. If possible the subspecies and lineage status, mating type and the comparative aggressiveness of tester isolates should be determined. With promising elm selections both high canopy and basal stem inoculation methods should be considered.

- On promising cultivars, in addition to xylem resistance, the potential for resistance to pathogen infection via beetle feeding wounds could also be investigated before release, using artificial feeding wounds (see Webber 1987). If possible alongside control cultivars of known feeding groove resistance (e.g. U. $\times$ holandica 'Commelin' and U. procera).

- Similarly, the relative attractiveness of a cultivar to beetle feeding could also be investigated before release, again in comparison with species/cultivars of known (low or high) attractiveness (e.g. U. glabra and U. procera).

- A combination of xylem resistance, feeding wound resistance and low feeding attraction could considerably enhance longer term field resistance of cultivars and their commercial and environmental utility.

- Ideally the influence of local disease pressures (size and density of susceptible hosts, pathogenic variability of the pathogen, beetle vector species) around selected, substantial populations of released elms could be monitored experimentally to assess the risk of directional selection for increased aggressiveness in O. novo-ulmi.

- In geographic locations where elm populations have frequent seed set, progenies of resistant selections should be monitored after deployment for any acquisition of genes (via introgressive hybridization) from native susceptible or exotic resistant elms.

- DED susceptibility in U. minor is directly correlated with geographic origin and date of bud burst, early flushing clones showing the least symptoms. This suggests that earliness of bud burst represents a mechanism of disease avoidance owing to an asynchrony between the susceptible period in the host and the time of natural infection by bark beetles. If precocity can be shown to be under genetic control it could also be selected for in a breeding programme.

- The symbiotic microbiome of selected cultivars might play a significant role in DED resistance. If confirmed, the microbiome of elm selections could be monitored or even manipulated to ensure that they are favourable to the maintenance of resistance.

- High standards of biosecurity including quarantine should be employed when moving resistant elms or other elm material between biogeographic zones or internationally. 
- In future biotechnology should enhance our understanding of the various resistance processes in elms and therefore the potential to deploy trees with highly durable and stable resistance in elm restoration. However because of the complexity of the DED pathosystem it remains uncertain whether elm genotyping (genome sequencing) will provide additional resistance markers suitable for accelerating the selection process.

- As resistant elms need to be deployed for many decades, if not centuries, elm breeding programmes cannot afford to get into the host-pathogen arms races, often involving rapid loss of resistance and a need for continued deployment of new genotypes, that characterise some agricultural host-pathogen systems (cf. Fry 2008; Croll and Lane 2016) and lead to the rapid loss of resistance and need for continued deployment of new genotypes. The need for highly durable resistance in elm implies aiming to achieve multigenically controlled, largely additive or quantitative resistance, avoiding dependence on major genes.

Funding Open access funding provided by Swedish University of Agricultural Sciences. Elm breeding in Spain is supported by Subdirección General de Política Forestal y Lucha contra la Desertificación (Ministerio para la Transición Ecológica y el Reto Demográfico). Juan A. Martín research on elm resistance was funded by the project AGL-2015-66952-R (MINECO/ERDF). C. Martínez-Arias was supported by an FPI pre-doctoral fellowship from the Spanish Ministry of Economy and Competitiveness. Louis Bernier's work on Dutch elm disease was funded by NSERC Discovery Grant RGPIN-2018-06607 and by Genome Canada, Genome British Columbia and Génome Québec within the framework of project bioSAFE (Biosurveillance of Alien Forest Enemies; Project Number 10106).

Data availabilty The datasets generated during and/or analysed during the current study are available from the corresponding author on reasonable request.

\section{Declarations}

Conflict of interest The authors have no conflicts of interest to declare that are relevant to the content of this article.

Open Access This article is licensed under a Creative Commons Attribution 4.0 International License, which permits use, sharing, adaptation, distribution and reproduction in any medium or format, as long as you give appropriate credit to the original author(s) and the source, provide a link to the Creative Commons licence, and indicate if changes were made. The images or other third party material in this article are included in the article's Creative Commons licence, unless indicated otherwise in a credit line to the material. If material is not included in the article's Creative Commons licence and your intended use is not permitted by statutory regulation or exceeds the permitted use, you will need to obtain permission directly from the copyright holder. To view a copy of this licence, visit http://creativecommons.org/licenses/by/4.0/.

\section{References}

Anderbrant O, Yuvaraj JK, Martin JA et al (2017) Feeding by Scolytus bark beetles to test for differently susceptible elm varieties. J Appl Entomol 141:417-420. https://doi.org/10.1111/jen.12354

Aoun M, Jacobi V, Boyle B, Bernier L (2010) Identification and monitoring of Ulmus americana transcripts during in vitro interactions with the Dutch elm disease pathogen Ophiostoma novo-ulmi. Physiol Mol Plant Pathol 74:254-266. https://doi.org/10.1016/j.pmpp.2010.04.003

Baker JE, Norris DM (1968) Further biological and chemical aspects of host selection by Scolytus multistriatus. Ann Entomol Soc Am 61:1248-1255. https://doi.org/10.1093/aesa/61.5.1248 
Banfield W (1941) Distribution by the sap stream of spores of three fungi that induce vascular wilt diseases of elm. J Agric Res 62:637-681

Beier GL, Blanchette RA (2018) Defence responses in the xylem of Ulmus americana cultivars after inoculation with Ophiostoma novo-ulmi. For Path 48:e12453. https://doi.org/10.1111/efp.12453

Beier GL, Blanchette RA (2020) Xylem characteristics in Ulmus americana cultivars and their potential use as a preliminary screening method for Dutch elm disease resistance. Forest Pathol 50:e12638. https:// doi.org/10.1111/efp.12638

Beier GL, Held BW, Giblin CP, Blanchette RA (2017a) Effects of inoculation timing on symptom development in Ulmus americana L. In: Pinchot CC, Knight KS, Haugen LM, Flower CE, Slavicek JM (eds.), In: Proceedings of the American elm restoration workshop 2016; 2016 October 25-27; Lewis Center, OH. Gen. Tech. Rep. NRS-P-174. Newtown Square, PA: U.S. Department of Agriculture, Forest Service, Northern Research Station: 30-36

Beier GL, Held BW, Giblin CP et al (2017b) American elm cultivars: Variation in compartmentalization of infection by Ophiostoma novo-ulmi and its effects on hydraulic conductivity. Forest Pathol 47:e12369. https://doi.org/10.1111/efp.12369

Bernier L, Yang D, Ouellette GB, Dessureault M (1996) Assessment of Phaeotheca dimorphospora for biological control of the Dutch elm disease pathogens, Ophiostoma ulmi and O. novo-ulmi. Plant Pathol 45:609-617. https://doi.org/10.1046/j.1365-3059.1996.d01-161.x

Bertolasi B, Leonarduzzi C, Piotti A et al (2015) A last stand in the Po valley: genetic structure and gene flow patterns in Ulmus minor and U. pumila. Ann Bot 115:683-692. https://doi.org/10.1093/aob/ $\operatorname{mcu} 256$

Brasier CM (1977) Inheritance of pathogenicity and cultural characters in Ceratocystis ulmi; hybridization of protoperithecial and non-aggressive strains. Trans Br Mycol Soc 68:45-52. https://doi.org/10. 1016/S0007-1536(77)80150-2

Brasier CM (1978) Mites and reproduction in Ceratocystis ulmi and other fungi. Trans Br Mycol Soc 70:81-89

Brasier CM (1981) Laboratory investigation of Ceratocystis ulmi. In: Stipes RJ, Campana RJ (eds) Compendium of Elm Disease. American Phytopathological Society, St Paul, Minnesota, pp 76-79

Brasier CM (1982). Occurrence of three sub-groups within Ceratocystis ulmi. In 'Proceedings of the Dutch elm disease Symposium and Workshop' Winnipeg, Manitoba, October 5-9, 1981, Kondo ES, Hiratsuka Y, Denyer WBC (eds.). Manitoba Department of Natural Resources, Manitoba, Canada, pp 298-321

Brasier CM (1983) A cytoplasmically transmitted disease of Ceratocystis ulmi. Nature 305:220-223. https:// doi.org/10.1038/305220a0

Brasier CM (1986a) The population biology of Dutch elm disease: Its principal features and some implications for other host-pathogen systems. Adv Plant Pathol 5:53-118

Brasier CM (1986b) Comparison of pathogencity and cultural characteristics in the EAN and NAN aggressive subgroups of Ophiostoma ulmi. Trans Br Mycol Soc 87:1-13. https://doi.org/10.1016/S00071536(86)80001-8

Brasier C (1986) The d-factor in Ceratocystis ulmi: its biological characteristics and implications for Dutch elm disease. In: Buck KW (ed) Fungal virology. CRC Press, Florida, pp 177-208

Brasier C (1987) Some genetical aspects of necrotophy with special reference to Ophiostoma ulmi. In: Day PR, Jellis GJ (eds) Genetics and plant pathogenesis. Blackwells, Oxford, pp 297-310

Brasier CM (1988) Rapid changes in genetic structure of epidemic populations of Ophiostoma ulmi. Nature 332:538-541. https://doi.org/10.1038/332538a0

Brasier CM (1991) Ophiostoma novo-ulmi sp. nov., causative agent of current Dutch elm disease pandemics. Mycopathologia 115:151-161. https://doi.org/10.1007/BF00462219

Brasier CM (2000) Viruses as biological control agents of the Dutch Elm disease fungus ophiostoma novo-ulmi. In: Dunn CP (ed) The Elms: breeding, conservation, and disease management. Springer, Boston, pp 201-212

Brasier CM (2001) Rapid evolution of introduced plant pathogens via interspecific hybridization: hybridization is leading to rapid evolution of Dutch elm disease and other fungal plant pathogens. Bioscience 51:123-133. https://doi.org/10.1641/0006-3568(2001)051[0123:REOIPP]2.0.CO;2

Brasier CM (2008) The biosecurity threat to the UK and global environment from international trade in plants. Plant Pathol 57:792-808. https://doi.org/10.1111/j.1365-3059.2008.01886.x

Brasier CM, Gibbs JN (1973) Origin of the Dutch elm disease epidemic in Britain. Nature 242:607-609. https://doi.org/10.1038/242607a0

Brasier CM, Kirk SA (1991) Rapid changes in O. novo-ulmi population structure at current epidemic fronts. Report on Forest Research 1991, HMSO, London, pp 37-38 
Brasier CM, Kirk SA (2000) Survival of clones of NAN Ophiostoma novo-ulmi around its probable centre of appearance in North America. Mycol Res 104:1322-1332. https://doi.org/10.1017/S095375620 0002732

Brasier CM, Kirk SA (2010) Rapid emergence of hybrids between the two subspecies of Ophiostoma novoulmi with a high level of pathogenic fitness. Plant Pathol 59:186-199. https://doi.org/10.1111/j.13653059.2009.02157.x

Brasier CM, Mehrotra MD (1995) Ophiostoma himal-ulmi sp. nov., a new species of Dutch elm disease fungus endemic to the Himalayas. Mycol Res 99:205-215. https://doi.org/10.1016/S0953-7562(09) 80887-3

Brasier CM, Webber JF (1987) Positive correlations between in vitro growth rate and pathogenesis in Ophiostoma ulmi. Plant Pathol 36:462-466. https://doi.org/10.1111/j.1365-3059.1987.tb02263.x

Brasier CM, Webber JF (2019) Is there evidence for post-epidemic attenuation in the Dutch elm disease pathogen Ophiostoma novo-ulmi ? Plant Pathol 68:921-929. https://doi.org/10.1111/ppa.13022

Brasier CM, Lea J, Rawlings MK (1981) The aggressive and non-aggressive strains of Ceratocystis ulmi have different temperature optima for growth. Trans Br Mycol Soc 76:213-218. https://doi.org/10. 1016/S0007-1536(81)80141-6

Brasier CM, Kirk SA, Pipe ND, Buck KW (1998) Rare interspecific hybrids in natural populations of the Dutch elm disease pathogens Ophiostoma ulmi and O. novo-ulmi. Mycol Res 102:45-57. https:// doi.org/10.1017/S0953756297004541

Brasier CM, Buck KW, Paoletti M, Crawford L, Kirk SA (2004) Molecular analysis of evolutionary changes in populations of Ophiostoma novo-ulmi. For Syst 13:93-103

Brasier CM, Franceschini S, Forster J, Kirk SA (2021) Enhanced outcrossing, directional selection and transgressive segregation drive evolution of novel phenotypes in hybrid swarms of the Dutch elm disease pathogen Ophiostoma novo-ulmi. J Fungi 7:452. https://doi.org/10.3390/jof7060452

Brasier CM (1996) Low genetic diversity of the Ophiostoma novo-ulmi population in North America. Mycologia 86: 951-964.Brasier CM (2000) Intercontinental spread and continuing evolution of the Dutch Elm disease pathogens. In: Dunn CP (ed) The elms: breeding, conservation, and disease management. Springer, Boston, pp 61-72

Brunet J, Zalapa JE, Pecori F, Santini A (2013) Hybridization and introgression between the exotic Siberian elm, Ulmus pumila, and the native field elm, U. minor, in Italy. Biol Invasions 15:2717-2730. https://doi.org/10.1007/s10530-013-0486-Z

Brunet J, Zalapa J, Guries R (2016) Conservation of genetic diversity in slippery elm (Ulmus rubra) in Wisconsin despite the devastating impact of Dutch elm disease. Conserv Genet 17:1001-1010. https://doi.org/10.1007/s10592-016-0838-1

Büchel K, Fenning RM, Gerschenzon J, Hilker M, Meiners T (2016) Elm defence against herbivores and pathogens: morphological, chemical and molecular regulation aspects. Phytochem Rev 15:961-983

Buiteveld J, Van Der Werf B, Hiemstra J (2015) Comparison of commercial elm cultivars and promising unreleased Dutch clones for resistance to Ophiostoma novo-ulmi. iForest 8:158-164. https://doi. org/10.3832/ifor1209-008

Busby PE, Ridout M, Newcombe G (2016) Fungal endophytes: modifiers of plant disease. Plant Mol Biol 90:645-655. https://doi.org/10.1007/s11103-015-0412-0

Byers J, Svihra P, Koehler C (1980) Attraction of elm bark beetles to cut limbs on elm. J Arboric 6:245-246

Cogolludo-Agustín MÁ, Agúndez D, Gil L (2000) Identification of native and hybrid elms in Spain using isozyme gene markers. Heredity 85:157-166. https://doi.org/10.1046/j.1365-2540.2000.00740.x

Collin E, Rondouin M, Joyeau C, Matz S, Raimbault P, Harvengt L, Bilger I, Guibert M (2020) Conservation and use of elm genetic resources in France: results and perspectives. iForest 13:41-47. https://doi.org/10.3832/ifor3065-013

Croll D, Laine AL (2016) What the population genetic structures of host and pathogen tell us about disease evolution. New Phytol 212:537-539

Dvořák M, Palovčíková D, Jankovský L (2012) The occurrence of endophytic fungus Phomopsis oblonga on elms in the area of southern Bohemia. J For Sci 52:531-535. https://doi.org/10.17221/4533-JFS

Elgersma DM (1970) Length and diameter of xylem vessels as factors in resistance of elms to Ceratocystis ulmi. Neth J Plant Pathol 76:179-182. https://doi.org/10.1007/BF01974328

Ellmore GS, Ewers FW (1985) Hydraulic conductivity in trunk xylem of elm, Ulmus americana. IAWA J 6:303-307. https://doi.org/10.1163/22941932-90000958

Ellstrand NC, Schierenbeck KA (2000) Hybridization as a stimulus for the evolution of invasiveness in plants? PNAS 97:7043-7050. https://doi.org/10.1073/pnas.97.13.7043

EPPO (2017) Pest risk analysis for Meloidogyne mali. EPPO, Paris Available at http://www.eppo.int/ QUARANTINE/Pest_Risk_Analysis/PRA_intro.htm and https://gd.eppo.int/taxon/MELGMA 
Et-Touil A, Brasier CM, Bernier L (1999) Localization of a pathogenicity gene in Ophiostoma novo-ulmi and evidence that it may be introgressed from O. ulmi. MPMI 12:6-15. https://doi.org/10.1094/ MPMI.1999.12.1.6

Et-Touil A, Dusabenyagasani M, Bouvet G et al (2019) Ophiostoma ulmi DNA naturally introgressed into an isolate of Ophiostoma novo-ulmi is clustered around pathogenicity and mating type loci. Phytoprotection 99:1-11. https://doi.org/10.7202/1059303ar

Faccoli M, Battisti A (1997) Observations on the transmission of Ophiostoma ulmi by the smaller elm bark beetles (Scolytus spp). In: Gregoire JC, Liebhold AM, Stephen FM, Day KR, Salom SM (eds.), Interacting cultural tactics into the management of bark beetle reforestation pests. Forest Service General Technical Report NE-236. Radnor, PA: USDA. pp. 172-176

Fairhurst CP, King CJ (1983) The effect of climatic factors on the dispersal of elm bark beetles. In: Research on Dutch elm disease in Europe. DA Burdekin, Forestry Commission Bulletin 60: 40-46: London: HMSO

Fenning TM, Tymens SS, Gartland JS, Brasier CM, Gartland KMA (1996) Transformation and regeneration of English elm using wild-type Agrobacterium tumefaciens. Plant Sci 116:37-46

Fransen J (1939) Lepenziekte, iepenspintkevers en beider bestrijding [Elm disease, elm bark beetles and their control]. Veenman and Zonen, Wageningen, The Netherland, pp 118 (in Dutch)

Fry W (2008) Phytophthora infestans: the plant (and R gene) destroyer. Mol Plant Pathol 9(3):385-402. https://doi.org/10.1111/j.1364-3703.2007.00465.x

Gartland JS, McHugh A, Fenning TM, Irvine RJ, Brasier CM, Gartland KMA (2000a) Regeneration of phenotypically normal English elm Ulmus procera plantlets following transformation with Agrobacterium tumefaciens binary vector. Tree Physiol 20:901-907

Gartland KMA, Gartland J, Fenning TM, McHugh AT, Irvine RJ, Main GD, Brasier CM (2000b) Genetic manipulations with elms. In: Dunn CP (ed) The elms: breeding, conservation, and disease management. Springer, Boston, pp 259-269

Gartland JS, Brasier CM, Fenning TM, Birch R, Gartland KMA (2001) Ri-plasmid mediated transformation of Ulmus procera (English elm). Plant Growth Regul 33:123-129

Ghalambor CK, McKay JK, Carroll SP, Reznick DN (2007) Adaptive versus non-adaptive phenotypic plasticity and the potential for contemporary adaptation in new environments. Funct Ecol 21:394-407. https://doi.org/10.1111/j.1365-2435.2007.01283.x

Ghelardini L, Falusi M, Santini A (2006) Variation in timing of bud-burst of Ulmus minor clones from different geographical origins. Can J for Res 36:1982-1991. https://doi.org/10.1139/x06-092

Ghelardini L, Santini A, Black-Samuelsson S et al (2010) Bud dormancy release in elm (Ulmus spp.) clones-a case study of photoperiod and temperature responses. Tree Physiol 30:264-274. https://doi. org/10.1093/treephys/tpp110

Gibbs JN, Brasier CM (1973) Correlation between cultural characters and pathogenicity in Ceratocystis ulmi from Britain, Europe and America. Nature 241:381-383. https://doi.org/10.1038/241381a0

Gibbs JN, Heybroek HM, Holmes FW (1972) Aggressive strain of Ceratocystis ulmi in Britain. Nature 236:121-122. https://doi.org/10.1038/236121a0

Gibbs JN, Brasier CM, McNabb HS, Heybroek HM (1975) Further studies on pathogenicity in Ceratocystis ulmi. For Pathol 5:161-174. https://doi.org/10.1111/j.1439-0329.1975.tb00461.X

Gil L, Fuentes-Utrilla P, Soto Á et al (2004) English elm is a 2,000-year-old Roman clone. Nature 431:1053. https://doi.org/10.1038/4311053a

Green C, Guries R, Smalley EB (1985) Early screening of elms for resistance to Ceratocystis ulmi. Plant Dis 69:60-63. https://doi.org/10.1094/PD-69-60

Griffin JJ, Jacobi WR, Gregory McPherson E, Sadof CS, McKenna JR, Gleason ML, Ward Gauthier N, Potter DA, Smitley DR, Adams GC, Brooks Gould A, Cash CR, Walla JA, Starrett MC, Chastagner G, Sibley JL, Krischik VA, Newby AF (2017) Ten-year performance of the United States national elm trial. Arboric Urban For 43:107-120

Grove JF (1983) Biochemical investigations related to Dutch elm disease. In: Research on Dutch elm disease in Europe. DA Burdekin, Forestry Commission Bulletin 60: 59-66: London: HMSO

Helcoski R, Tepley AJ, Mcgarvey JC et al (2019) No significant increase in tree mortality following coring in a temperate hardwood forest. Tree-Ring Res 75:67. https://doi.org/10.3959/1536-1098-75.1.67

Hessenauer P, Fijarczyk A, Martin H et al (2020) Hybridization and introgression drive genome evolution of Dutch elm disease pathogens. Nat Ecol Evol 4:626-638. https://doi.org/10.1038/s41559-020-1133-6

Heybroek HM (1957) Elm-breeding in the Netherlands. Sylvae Genet 6:112-117

Heybroek HM (1979) Mini-monograph of elms in agroforestry, technical consultation on fast-growing broadleaved trees for Mediterranean and temperate zones. FAO, FO: FGB-79-8/7 423-441

Heybroek H (1993) The Dutch elm breeding programme. In: Sticklen MB, Sherald JL (eds) Dutch elm disease research, cellular and molecular approaches. Springer, New York, pp 16-25 
Hubbes M (2004) Induced resistance for the control of Dutch elm disease. For Syst 13:185-196

IPCC (2014) AR5 Synthesis Report: Climate Change 2014. Geneva (Switzerland)

Isik K, Kleinschmit J (2003) Stability-related parameters and their evaluation in a 17-year old Norway spruce clonal test series. Silvae Genetica 52:133-138

Jiménez-López L, Eugenio ME, Ibarra D et al (2020) Cellulose nanofibers from a Dutch elm disease-resistant Ulmus minor clone. Polymers 12:2450. https://doi.org/10.3390/polym12112450

Kais A, Smalley E, Riker A (1962) Environment and development of Dutch elm disease. Phytopathology 52:1191-1196

Kile GA, Brasier CM (1990) Inheritance and inter-relationship of fitness characters in progeny of an aggressive $\times$ non-aggressive cross of Ophiostoma ulmi. Mycol Res 94:514-522. https://doi.org/10.1016/ S0953-7562(10)80013-9

Klimetzek D, Kopp HP (1983). Scolytid pheromone research in West Germany. In: Research on Dutch elm disease in Europe. DA Burdekin, For Comm Bull 60: 50-58

Knight K, Haugen L, Pinchot C, et al (2017) American elm (Ulmus americana) in restoration plantings: a review. In: Pinchot C, Cornelia C; Knight, Kathleen S; Haugen, Linda M; Flower, Charles E; Slavicek, James M (eds.), Proceedings of the American elm restoration workshop 2016; 2016 October 25-27; Lewis Center, OH Gen Tech Rep NRS-P-174 Newtown Square, PA: US Department of Agriculture, Forest Service, Northern Research Station, pp 133-140

Lam BS, Strobel GA, Harrison LA, Lam ST (1987) Transposon mutagenesis and tagging of fluorescent Pseudomonas: Antimycotic production is necessary for control of Dutch elm disease. Proc Natl Acad Sci 84:6447-6451. https://doi.org/10.1073/pnas.84.18.6447

Landwehr VR, Phillipsen WJ, Ascerno ME, Hatch R (1981) Attraction of the native elm bark beetle to American elm after the pruning of branches. J Econ Entomol 74:577-580. https://doi.org/10.1093/ jee/74.5.577

Lanier GN, Silverstein RM, Peacock JW (1976) Attractant pheromone of the European elm bark beetle Scolytus multistriatus: isolation, identification, synthesis and utilization studies. In: Anderson JF, Kaya HK (eds) Perspectives in forest entomology. Academic Press, New York, pp 149-175

Lanier GN, Gore WE, Pearce GT, Peacock JW, Silverstein RM (1977) Response of the European elm bark beetle Scolytus multistriatus to isolamers and components of its pheromone. J Chem Ecol $3: 1-8$

Lovisolo C, Schubert A (1998) Effects of water stress on vessel size and xylem hydraulic conductivity in Vitis vinifera L. J Exp Bot 49:693-700

Macaya-Sanz D, Witzell J, Collada C, Gil L, Martín JA (2020) Structure of core fungal endobiome in Ulmus minor: patterns within the tree and across genotypes differing in tolerance to Dutch elm disease. bioRxiv 2020.06.23.166454. https://doi.org/10.1101/2020.06.23.166454

Martín JA, Solla A, Burón M et al (2006) Historical, ecological, taxonomic and health characterization of the relict elm stand of Rivas-Vaciamadrid (Madrid). For Syst 15:208-217. https://doi.org/10. 5424/srf/2006152-00965

Martín JA, Solla A, Coimbra MA, Gil L (2008a) Metabolic fingerprinting allows discrimination between Ulmus pumila and $U$. minor, and between $U$. minor clones of different susceptibility to Dutch elm disease. Forest Pathol 38:244-256. https://doi.org/10.1111/j.1439-0329.2007.00542.x

Martín JA, Solla A, Domingues MR et al (2008b) Exogenous phenol increase resistance of Ulmus minor to Dutch elm disease through formation of suberin-like compounds on xylem tissues. Environ Exp Bot 64:97-104. https://doi.org/10.1016/j.envexpbot.2008.05.004

Martín JA, Solla A, Gil L, García-Vallejo MC (2010a) Phenological and histochemical changes of Ulmus minor due to root absorption of phenol: Implications for resistance to DED. Environ Exp Bot 69:175-182. https://doi.org/10.1016/j.envexpbot.2010.04.001

Martín JA, Solla A, Witzell J et al (2010b) Antifungal effect and reduction of Ulmus minor symptoms to Ophiostoma novo-ulmi by carvacrol and salicylic acid. Eur J Plant Pathol 127:21-32. https://doi. org/10.1007/s10658-009-9567-3

Martín JA, Fuentes-Utrilla P, Gil L, Witzell J (2010c) Ecological factors in Dutch elm disease complex in Europe: a review. Ecol Bull 53:209-224

Martín JA, Solla A, García-Vallejo MC, Gil L (2012) Chemical changes in Ulmus minor xylem tissue after salicylic acid or carvacrol treatments are associated with enhanced resistance to Ophiostoma novo-ulmi. Phytochemistry 83:104-109. https://doi.org/10.1016/j.phytochem.2012.07.017

Martín JA, Solla A, Ruiz-Villar M, Gil L (2013a) Vessel length and conductivity of Ulmus branches: ontogenetic changes and relation to resistance to Dutch elm disease. Trees 27:1239-1248. https:// doi.org/10.1007/s00468-013-0872-2 
Martín JA, Witzell J, Blumenstein K et al (2013b) Resistance to Dutch elm disease reduces presence of xylem endophytic fungi in elms (Ulmus spp.). PLoS ONE 8:e56987. https://doi.org/10.1371/journ al.pone.0056987

Martín J, Solla A, Venturas M et al (2015) Seven Ulmus minor clones tolerant to Ophiostoma novo-ulmi registered as forest reproductive material in Spain. iForest 8:172-180. https://doi.org/10.3832/ ifor1224-008

Martín JA, Sobrino-Plata J, Rodríguez-Calcerrada J et al (2019a) Breeding and scientific advances in the fight against Dutch elm disease: will they allow the use of elms in forest restoration? New for 50:183-215. https://doi.org/10.1007/s11056-018-9640-x

Martín JA, Sobrino-Plata J, Coira B et al (2019b) Growth resilience and oxidative burst control as tolerance factors to Ophiostoma novo-ulmi in Ulmus minor. Tree Physiol 39:1512-1524. https://doi. org/10.1093/treephys/tpz067

Martín JA, Solla A, Oszako T, Gil L (2021) Characterizing offspring of Dutch elm disease-resistant trees (Ulmus minor Mill.). For Int J For Res 94(3):374-385. https://doi.org/10.1093/forestry/cpaa040

Martínez-Arias C, Sobrino-Plata J, Macaya-Sanz D et al (2020) Changes in plant function and root mycobiome caused by flood and drought in a riparian tree. Tree Physiol 40:886-903. https://doi.org/10.1093/ treephys/tpaa031

Martínez-Arias C, Sobrino-Plata J, Ormeño-Moncalvillo S et al (2021) Endophyte inoculation enhances Ulmus minor resistance to Dutch elm disease. Fungal Ecol 50:101024. https://doi.org/10.1016/j. funeco.2020.101024

Martín-Sampedro R, Eugenio ME, Fillat Ú et al (2019) Biorefinery of lignocellulosic biomass from an elm clone: production of fermentable sugars and lignin-derived biochar for energy and environmental applications. Energy Technol 7:277-287. https://doi.org/10.1002/ente.201800685

McLeod G, Gries R, von Reuß SH et al (2005) The pathogen causing Dutch elm disease makes host trees attract insect vectors. Proc R Soc B 272:2499-2503. https://doi.org/10.1098/rspb.2005.3202

McNabb HS, Heybroek HM, Macdonald WL (1970) Anatomical factors in resistance to Dutch elm disease. Neth J Plant Pathol 76:196-205. https://doi.org/10.1007/BF01974331

Mehmood A (2019) Antibacterial and antioxidant activity of biosynthesized silver nanoparticles from Ulmus wallichiana Planch leaf extract. Farmacia 67:662-669. https://doi.org/10.31925/farmacia. 2019.4.16

Mitchell AG, Brasier CM (1994) Contrasting structure of European and North American populations of Ophiostoma ulmi. Mycol Res 98:576-582. https://doi.org/10.1016/S0953-7562(09)80482-6

Mittempergher L, Santini A (2004) The history of elm breeding. For Syst 13:161-177. https://doi.org/10. 5424/821

Moser JC, Konrad H, Blomquist SR, Kirisits T (2010) Do mites phoretic on elm bark beetles contribute to the transmission of Dutch elm disease? Naturwissenschaften 97:219-227. https://doi.org/10.1007/ s00114-009-0630-X

Newbanks D (1983) Evidence for xylem dysfunction by embolization in Dutch elm disease. Phytopathology 73:1060. https://doi.org/10.1094/Phyto-73-1060

Nielsen LR, Kjær ED (2010) Gene flow and mating patterns in individuals of wych elm (Ulmus glabra) in forest and open land after the influence of Dutch elm disease. Conserv Genet 11:257-268. https://doi. org/10.1007/s10592-009-0028-5

Nigg M, Bernier L (2016) From yeast to hypha: defining transcriptomic signatures of the morphological switch in the dimorphic fungal pathogen Ophiostoma novo-ulmi. BMC Genom 17:920. https://doi. org/10.1186/s12864-016-3251-8

Noyer E, Lachenbruch B, Dlouhá J et al (2017) Xylem traits in European beech (Fagus sylvatica L.) display a large plasticity in response to canopy release. Ann For Sci 74:46. https://doi.org/10.1007/ s13595-017-0634-1

O'Callaghan DP, Fairhurst CP (1983). Evaluation of the trap tree technique for the control of Dutch elm disease in northwest England. In: Research on Dutch elm disease in Europe. DA Burdekin. For Comm Bull 60: 23-28

Paine TD, Birch MC, Miller JC (1984) Use of pheromone traps to suppress populations of Scolytus multistriatus (Marsham) (Coleoptera: Scolytidae) in three isolated communities of elms. Agr Ecosyst Environ 11:309-318. https://doi.org/10.1016/0167-8809(84)90004-5

Pajares JA (2004) Elm breeding for resistance against bark beetles. For Syst 13:207-2015

Pajares JA, García S, Díez JJ, Martín D, García-Vallejo MC (2004) Feeding responses by Scolytus scolytus to twig bark extracts from elms. For Syst 13:217-225

Paoletti M, Buck KW, Brasier CM (2006) Selective acquisition of novel mating type and vegetative incompatibility genes via interspecies gene transfer in the globally invading eukaryote Ophiostoma novoulmi. Mol Ecol 15:249-262. https://doi.org/10.1111/j.1365-294X.2005.02728.x 
Peace T (1960) The status and development of elm disease in Britain. For Comm Bull 33:44

Pecori F, Ghelardini L, Luchi N et al (2017) Lights and shadows of a possible strategy to cope with alien and destructive forest pathogens: the example of breeding for resistance to Dutch elm disease in Italy. Balt for 23:255

Pepori AL, Bettini PP, Comparini C et al (2018) Geosmithia-Ophiostoma: a new fungus-fungus association. Microb Ecol 75:632-646. https://doi.org/10.1007/s00248-017-1062-3

Pinchot C, Flower C, Knight K, et al. (2017) Development of new Dutch Elm disease-tolerant selections for restoration of the American elm in urban and forested landscapes. In: Sniezko RA, Man G, Hipkins V, Woeste K, Gwaze D, Kliejunas JT, McTeague BA (eds), Tech Cords 2017 Gene conservation of tree species-banking on the future. In: Proceedings of a workshop Gen Tech Rep PNW-GTR-963 Portland, OR: US Department of Agriculture, Forest Service, Pacific Northwest Research Station 53-63

Pouzoulet J, Rolshausen PE, Charbois R et al (2020) Behind the curtain of the compartmentalization process: Exploring how xylem vessel diameter impacts vascular pathogen resistance. Plant Cell Environ 43:2782-2796. https://doi.org/10.1111/pce.13848

Prior T, Tozer H, Yale R et al (2019) First report of Meloidogyne mali causing root galling to elm trees in the UK. New Dis Reps 39:10-10. https://doi.org/10.5197/j.2044-0588.2019.039.010

Raghavendra AKH, Newcombe G (2013) The contribution of foliar endophytes to quantitative resistance to Melampsora rust. New Phytol 197:909-918. https://doi.org/10.1111/nph.12066

Redman RS, Kim YO, Woodward CJDA et al (2011) Increased fitness of rice plants to abiotic stress via habitat adapted symbiosis: a strategy for mitigating impacts of climate change. PLoS ONE 6:e14823. https://doi.org/10.1371/journal.pone.0014823

Resende MFR Jr, Muñoz P, Acosta JJ, Peter GF, Davis JM, Grattapaglia D, Resende MDV, Kirst M (2012) Accelerating the domestication of trees using genomic selection: accuracy of prediction models across ages and environments. New Phytol 193:617-624. https://doi.org/10.1111/j.1469-8137.2011. 03895.x

Richens RH (1983) Elm. Cambridge University Press, Cambridge

Sachetti P, Tiber R, Mittempergher L (1990) Preference of Scolytus scolytus Masham in twig crotch feeding on two elm species. Redia 73:347-354

Santini A, Casini N, Di Lonardo V, Raddi P (1997) Canker resistance stability of some Cupressus sempervirens clones to Seiridium cardinale. J Genet Breed 51:269-277

Santini A, Fagnani A, Ferrini F, Mittempergher L (2002) "San Zanobi" and "Plinio" elm trees. HortScience 37:1139-1141. https://doi.org/10.21273/HORTSCI.37.7.1139

Santini A, Fagnani A, Ferrini F et al (2005a) Variation among Italian and French elm clones in their response to Ophiostoma novo-ulmi inoculation. Forest Pathol 35:183-193. https://doi.org/10.1111/j. 1439-0329.2005.00401.x

Santini A, Montaghi A, Vendramin GG, Capretti P (2005b) Analysis of the Italian Dutch elm disease fungal population. J Phytopathol 153:73-79. https://doi.org/10.1111/j.1439-0434.2004.00931.x

Santini A, Fagnani A, Ferrini F et al (2007) 'Fiorente' and 'Arno' Elm trees. HortScience 42:712-714. https://doi.org/10.21273/HORTSCI.42.3.712

Santini A, La Porta N, Ghelardini L, Mittempergher L (2008) Breeding against Dutch elm disease adapted to the Mediterranean climate. Euphytica 163:45-56. https://doi.org/10.1007/s10681-007-9573-5

Santini A, Pecori F, Pepori AL et al (2010) Genotype $\times$ environment interaction and growth stability of several elm clones resistant to Dutch elm disease. For Ecol Manag 260:1017-1025. https://doi.org/10. 1016/j.foreco.2010.06.025

Santini A, Pecori F, Pepori A, Brookes A (2012) 'Morfeo' Elm: a new variety resistant to Dutch elm disease: 'Morfeo' Elm. Forest Pathol 42:171-176. https://doi.org/10.1111/j.1439-0329.2011.00737.x

Santini A, Ghelardini L, De Pace CD et al (2013) Biogeographical patterns and determinants of invasion by forest pathogens in Europe. New Phytol 197:238-250. https://doi.org/10.1111/j.1469-8137.2012. 04364.x

Scheffer RJ, Heybroek HM, Elgersma DM (1980) Symptom expression in elms after inoculation with combination of an aggressive and a non-aggressive strain of Ophiostoma ulmi. Neth J Plant Pathol 86:315-317. https://doi.org/10.1007/BF01977289

Scheffer RJ, Voeten JGWF, Guries RP (2008) Biological control of Dutch elm disease. Plant Dis 92:192200. https://doi.org/10.1094/PDIS-92-2-0192

Shade A, Handelsman J (2012) Beyond the Venn diagram: the hunt for a core microbiome: the hunt for a core microbiome. Environ Microbiol 14:4-12. https://doi.org/10.1111/j.1462-2920.2011.02585.x

Sherif SM, Shukla MR, Murch SJ, Bernier L, Saxena PK (2016) Simultaneous induction of jasmonic acid and disease-responsive genes signifies tolerance of American elm to Dutch elm disease. Sci Rep 6:21934. https://doi.org/10.1038/srep21934 
Sinclair WA (1975) Anatomical marker for resistance of Ulmus americana to Ceratocystis ulmi. Phytopathology 65:349. https://doi.org/10.1094/Phyto-65-349

Smalley E (1963) Seasonal fluctuations in susceptibility of young elm seedlings to Dutch elm disease. Phytopatholology 53:846-853

Smalley EB, Guries RP (1993) Breeding elms for resistance to Dutch elm disease. Annu Rev Phytopathol 31:325-354. https://doi.org/10.1146/annurev.py.31.090193.001545

Smalley EB, Kais AG (1966) Seasonal variations in the resistance of various elm species to Dutch elm disease. In: Gerhold HD, Schreiner EJ, McDERMOTT RE, Winieski JA (eds.), Breeding Pest-Resistant Trees. Pergamon, pp 279-287

Solla A, Gil L (2001a) Selección de olmos resistentes a la grafiosis: I-Influencia de la composición del inóculo infectivo. Bol San Veg Plagas 27:355-362

Solla A, Gil L (2001b) Selección de olmos resistentes a la grafiosis. II. Influencia de la repetición de las inoculaciones. Boletín Sanidad Vegetal Plagas 27:363-372

Solla A, Gil L (2002a) Influence of water stress on Dutch elm disease symptoms in Ulmus minor. Can J Bot 80:810-817. https://doi.org/10.1139/b02-067

Solla A, Gil L (2002b) Xylem vessel diameter as a factor in resistance of Ulmus minor to Ophiostoma novo-ulmi. Forest Pathol 32:123-134. https://doi.org/10.1046/j.1439-0329.2002.00274.X

Solla A, Gil L (2003) Evaluating Verticillium dahliae for biological control of Ophiostoma novo-ulmi in Ulmus minor. Plant Pathol 52:579-585. https://doi.org/10.1046/j.1365-3059.2003.00921.x

Solla A, Burón M, Gil L (2001) Relación entre parámetros de intercambio gaseoso y los primeros síntomas de Ulmus minor Mill. a la grafiosis. For Syst 10:151-163

Solla A, Bohnens J, Collin E et al (2005a) Screening European elms for resistance to Ophiostoma novoulmi. Forest Science 51:134-141. https://doi.org/10.1093/forestscience/51.2.134

Solla A, Martin JA, Corral P, Gil L (2005) Seasonal changes in wood formation of Ulmus pumila and $U$. minor and its relation with Dutch elm disease. New Phytologist 166(3):1025-1034. https://doi.org/ 10.1111/J.1469-8137.2005.01384.X

Solla A, Martín JA, Ouellette GB, Gil L (2005c) Influence of plant age on symptom development in Ulmus minor following inoculation by Ophiostoma novo-ulmi. Plant Dis 89:1035-1040. https:// doi.org/10.1094/PD-89-1035

Solla A, Dacasa MC, Nasmith C et al (2008) Analysis of Spanish populations of Ophiostoma ulmi and O. novo-ulmi using phenotypic characteristics and RAPD markers. Plant Pathol 57:33-44. https:// doi.org/10.1111/j.1365-3059.2007.01692.x

Solla A, López-Almansa J, Martín J, Gil L (2015) Genetic variation and heritability estimates of Ulmus minor and Ulmus pumila hybrids for budburst, growth and tolerance to Ophiostoma novo-ulmi. iForest 8:422-430. https://doi.org/10.3832/ifor1227-007

Solla A, Milanović S, Gallardo A et al (2016) Genetic determination of tannins and herbivore resistance in Quercus ilex. Tree Genet Genom 12:117. https://doi.org/10.1007/s11295-016-1069-9

Sperry JS, Tyree MT (1988) Mechanism of water stress-induced xylem embolism. Plant Physiol 88:581-587

Sutherland ML, Brasier CM (1997) A comparison of thirteen d-factors as potential biological control agents of Ophiostoma novo-ulmi. Plant Pathol 46:680-693. https://doi.org/10.1046/j.1365-3059. 1997.d01-62.x

Sutherland ML, Mittempergher L, Brasier CM (1995) Experiments on the control of Dutch elm disease by induced host resistance. Eur J For Pathol 25:307-318

Sutherland ML, Pearson S, Brasier CM (1997) The influence of temperature and light on defoliation levels of elm by Dutch elm disease. Phytopathology 87:576-581. https://doi.org/10.1094/PHYTO. 1997.87.6.576

Tchernoff V (1965) Methods for screening and for the rapid selection of elms for resistance to Dutch elm disease. Acta Botanica Neerlandica 14:409-452. https://doi.org/10.1111/j.1438-8677.1965.tb00204.x

Terhonen E, Blumenstein K, Kovalchuk A, Asiegbu FO (2019) Forest tree microbiomes and associated fungal endophytes: functional roles and impact on forest health. Forests 10:42. https://doi.org/10. 3390/f10010042

Tosi M, Mitter EK, Gaiero J, Dunfield K (2020) It takes three to tango: the importance of microbes, host plant, and soil management to elucidate manipulation strategies for the plant microbiome. Can $\mathrm{J}$ Microbiol 66:413-433. https://doi.org/10.1139/cjm-2020-0085

Townsend AM (2000) USDA genetic research on elms. In: Dunn CP (ed) The elms: breeding, conservation, and disease management. Springer, Boston, pp 271-278

Townsend AM, Bentz SE, Johnson GR (1995) Variation in response of selected American elm clones to Ophiostoma ulmi. J Environ Hortic 13:126-128. https://doi.org/10.24266/0738-2898-13.3.126 
Townsend AM, Bentz SE, Douglass LW (2005) Evaluation of 19 American elm clones for tolerance to Dutch elm disease. J Environ Hortic 23:21-24. https://doi.org/10.24266/0738-2898-23.1.21

Valladares F, Gianoli E, Gómez JM (2007) Ecological limits to plant phenotypic plasticity. New Phytol 176:749-763. https://doi.org/10.1111/j.1469-8137.2007.02275.x

Venegas-González A, Von Arx G, Chagas MP, Filho MT (2015) Plasticity in xylem anatomical traits of two tropical species in response to intra-seasonal climate variability. Trees 29:423-435. https:// doi.org/10.1007/s00468-014-1121-z

Vivas M, Martín JA, Gil L, Solla A (2012) Evaluating methyl jasmonate for induction of resistance to Fusarium oxysporum, F. circinatum and Ophiostoma novo-ulmi. For Syst 21:289-299. https://doi. org/10.5424/fs/2012212-02172

Webber J (1981) A natural biological control of Dutch elm disease. Nature 292:449-451. https://doi.org/ $10.1038 / 292449 \mathrm{a} 0$

Webber JF (1987) Influence of the $\mathrm{d} 2$ factor on survival and infection by the Dutch elm disease pathogen Ophiostoma ulmi. Plant Pathol 36:531-538. https://doi.org/10.1111/j.1365-3059.1987.tb02270.x

Webber JF (1990) Relative effectiveness of Scolytus scolytus, S. multistriatus and S. kirschi as vectors of Dutch elm disease. Eur J for Pathol 20:184-192. https://doi.org/10.1111/j.1439-0329.1990.tb01129.x

Webber JF (1993) D factors and their potential for controlling Dutch elm disease. In: Sticklen MB, Sherald JL (eds) Dutch Elm disease research: cellular and molecular approaches. Springer, New York, pp 322-332

Webber J (2000) Insect vector behaviour and the evolution of Dutch elm disease. In: Dunn CP (ed) The elms: breeding, conservation and disease management. Kluwer, Boston, pp 47-60

Webber J (2004) Experimental studies on factors influencing the transmission of Dutch elm disease. For Syst 13:197-205

Webber J, Brasier C (1984) The transmission of Dutch elm disease: a study of the processes involved. In: Anderson JM, Rayner ADM, Walton D (eds) Invertebrate-microbial interactions. Cambridge University Press, pp 271-306

Webber J, Brasier C (1994) Differential resistance of elms to infection via beetle feeding wounds. Report on Forest Research 1994 HMSO London, UK pp 27

Webber JF, Hedger JN (1986) Comparison of interactions between Ceratocystis ulmi and elm bark saprobes in vitro and in vivo. Trans Br Mycol Soc 86:93-101

Webber J, Kirby S (1983) Host feeding preference of Scolytus scolytus. Research on Dutch elm disease in Europe, Forestry Commision Bulletin 60. HMSO, London, pp 47-49

Webber J, Brasier C, Mitchell A (1988) The role of the saprophytic phase in Dutch elm disease. Symp Ser Br Mycol Soc 13:298-313

Wei Z, Jousset A (2017) Plant breeding goes microbial. Trends Plant Sci 22:555-558. https://doi.org/10. 1016/j.tplants.2017.05.009

Witzell J, Martín JA, Blumenstein K (2014) Ecological aspects of endophyte-based biocontrol of forest diseases. In: Verma VC, Gange AC (eds) Advances in endophytic research. Springer India, New Delhi, pp 321-333

Woodcock P, Marzano M, Quine CP (2019) Key lessons from resistant tree breeding programmes in the Northern Hemisphere. Ann for Sci 76:51. https://doi.org/10.1007/s13595-019-0826-y

Zalapa JE, Brunet J, Guries RP (2009) Patterns of hybridization and introgression between invasive Ulmus pumila (Ulmaceae) and native U. rubra. Am J Bot 96:1116-1128. https://doi.org/10.3732/ajb.08003 34

Publisher's Note Springer Nature remains neutral with regard to jurisdictional claims in published maps and institutional affiliations.

\section{Authors and Affiliations}

\section{Juan A. Martín ${ }^{1,7}$. Jorge Domínguez ${ }^{1,2}$ - Alejandro Solla ${ }^{3}$. Clive M. Brasier ${ }^{4}$. Joan F. Webber ${ }^{4}$. Alberto Santini ${ }^{5}$. Clara Martínez-Arias ${ }^{1} \cdot$ Louis Bernier $^{6} \cdot$ Luis Gil $^{1}$}

1 Departamento de Sistemas y Recursos Naturales, ETSI Montes, Forestal y del Medio Natural, Universidad Politécnica de Madrid, Ciudad Universitaria s/n, 28040 Madrid, Spain

2 Centro Nacional de Recursos Genéticos Forestales Puerta de Hierro. TRAGSA., Ctra. de la Coruña, Km 7.5, 28040 Madrid, Spain 
3 Faculty of Forestry, Institute for Dehesa Research (INDEHESA), University of Extremadura, Avenida Virgen del Puerto 2, 10600 Plasencia, Spain

4 Forest Research, Alice Holt Lodge, Farnham GU10 4LH, UK

5 Istituto per la Protezione Sostenibile delle Piante - C.N.R., Via Madonna del Piano, 10, 50019 Sesto Fiorentino, Italy

6 Centre d'étude de la Forêt (CEF), Université Laval, Quebec City, QC G1V 0A6, Canada

7 Southern Swedish Forest Research Centre, Swedish University of Agricultural Sciences (SLU), Alnarp, Sweden 